

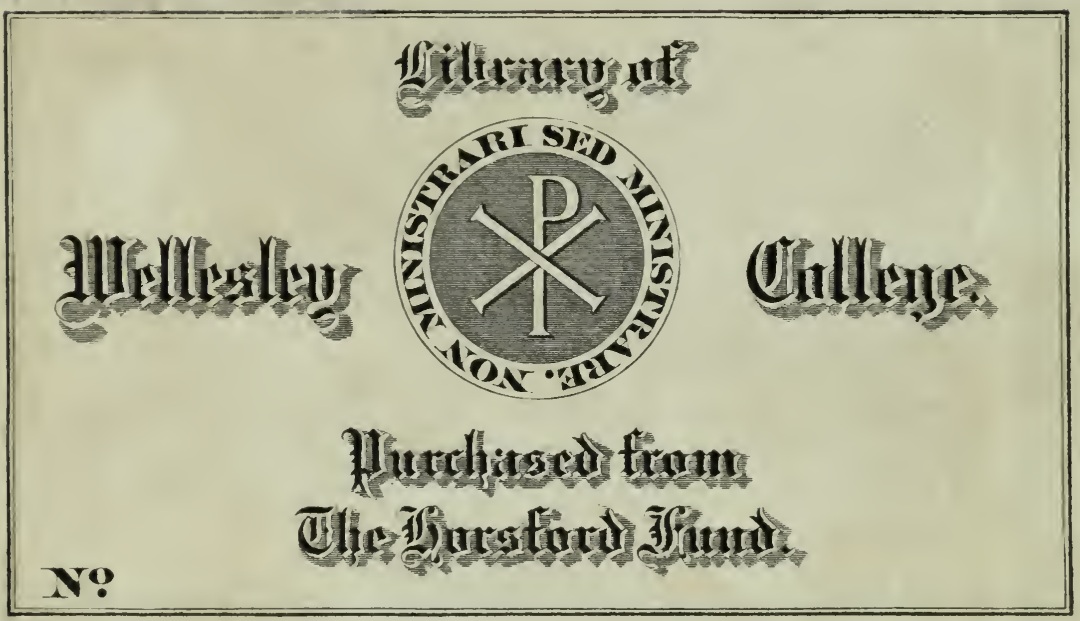




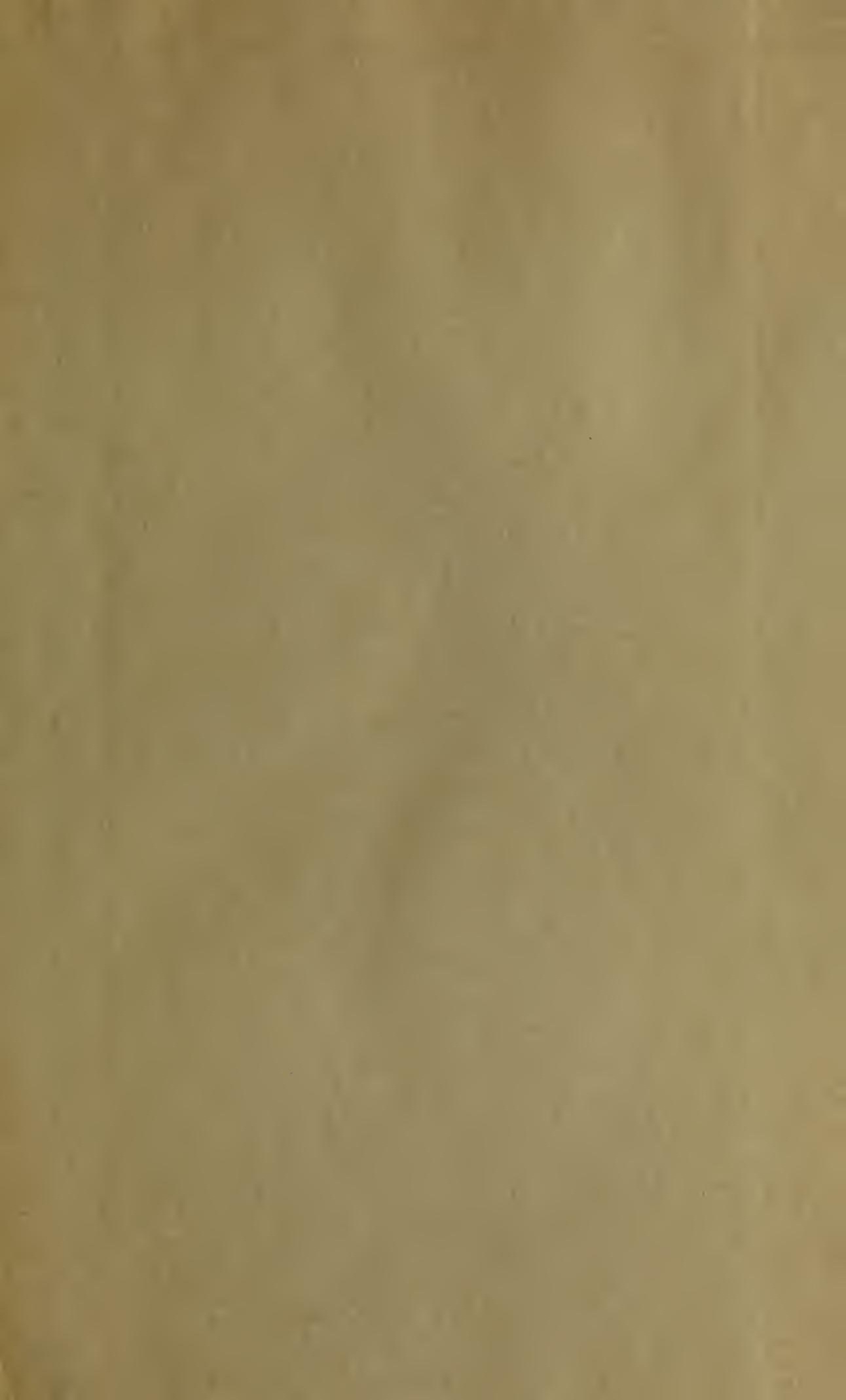


4 
Digitized by the Internet Archive in 2014 


\section{ON ORTHOGENESIS}

AND

\section{THE IMPOTENCE OF NATURAL SELECTION IN SPECIES-FORMATION.}

BY

TH. EIMER

Professor of Zoölogy in TUebingen

AN ADDRESS DELIVERED AT THE LEYDEN CONGRESS OF ZOOLOGISTS, SEPTEMBER 19, 1895

TRANSLATED BY

THOMAS J. MCCORMACK

\section{CHICAGO}

THE OPEN COURT PUBLISHING COMPANY

LONDON : Kegan Paul, Trench, Trübner \& Co.

1898

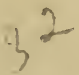




\section{4 \\ Copyright by \\ The Open Court Publishing Co. \\ 1897.}

SCIENCE

$$
\begin{aligned}
& \text { QH } \\
& 366 \\
& \text { E35 }
\end{aligned}
$$




\section{PRELIMINARY REMARKS.}

THE ADDRESS on Germinal Selection which Weismann deliv1 ered at the Leyden Congress of Zoölogists having appeared in the Religion of Science series in an English translation, it seems fitting that the American and English public should also be made acquainted with the paper which I read three days later at the same Congress on the same subject, viz., definitely directed evolution-to explain which Weismann's theory of germinal selection was propounded. I did not speak in the general session of the International Congress of Zoologists, but in a special session only, and for this reason, if for no other, the contents of my paper have as yet become little known. Furthermore, my opponent has since published his lecture in separate pamphlet form (Jena, I896; Eng. trans. in No. I9 of the Religion of Science Library, Chicago, 1896), and not without substantial alterations. Again, whilst the speculations upon which Weismann's germinal selection rests, have been made public in numerous short separate publications, which were as a rule immediately translated into English, my views, which are at diametrical variance with the aforesaid speculations, repose upon an unwieldy mass of facts, not easily accessible to the intelligent public at large. One only of my works has been translated into English, namely, my book on Die Entstehung der.Arten auf Grund von Vererbung erworbener Eigenschaften nach den Gesetzen organischen Wachsens, I., Jena, I888, under the altered title of Organic Evolution, Macmillan, London, r889. In this book I opposed, and was in fact the first to oppose, the main tenets of the Weismannian hypothesis of germ-plasm, and I have had the satisfaction of seeing 
that the numerous arguments which support this hypothesis have from year to year been modified in my favor.

Whilst, however, Weismann has never ceased altering his hypotheses, he has yet refused to abandon certain fundamental tenets of the same, as his denial of the heredity of acquired characters, his advocacy of chance in the production of variations, and the exclusive dominancy of utility show. He has thus, the more he has altered his views, plunged himself the more inextricably into untenable contradictions, the most exemplary of which is his germinal selection. But germinal selection is nothing else than an attempt to render innocuous, or at least to force into conformity with his theory, the facts established during the last twenty years by myself and my pupils, according to which the modification of organisms takes place not accidentally but in a few perfectly determinate directions. Like facts have also been established in America by Prof. Alpheus Hyatt with reference to the transformation of Ammonites.

Definitely directed evolution, orthogenesis, is a universally valid law. It disproves definitively Weismann's contention of the omnipotence of natural selection-a mere exaggeration of Darwinism and implicitly involving the other view which Weismann has heretofore upheld unconditionally and which Darwin too had once advocated, that all existing characters of animals have some utility. Orthogenesis shows that organisms develop in definite directions without the least regard for utility through purely physiological causes as the result of organic growth, as I term the process. No absolutely injurious character could in the nature of the case continue to exist, but neither could natural selection which Weismann assumes to be the only determining factor in transformation have any efficacy unless something previously existed which from being already useful could be taken hold of by natural selection and so made to serve its purposes.

I have insisted upon this simple proposition for years in refutation of the claims of my opponent, and shown that numerous characters, particularly with reference to the markings of animals, exist and are developed without utility being in the remotest de- 
gree concerned in the process. I have cited again and again proofs which show that the transformations of the organic world, namely, its "organic growth," its organophysis or morphophysis, are the result of outward influences such as climate, nutriment, etc., acting on a given constitution, and I have based my contentions on experiments, showing, for example, the artificial effects of heat and cold on butterflies, the results of which experiments accorded perfectly with the deductions which I had drawn from my researches on the formation of species in butterflies (Papilionida) as affected by geographical distribution.

Now Weismann attempts to neutralise the significance of orthogenesis, which is so fatal to his theories, by asserting that definite directions of evolution are themselves selected by utility, and he asserts this in the same breath with the diametrically opposed proposition that selection constantly finds all possible variations ready at hand for its work, and that the variations are at first really accidental and not useless (though at the end of his paper he takes the opposite stand). For I had repeatedly objected, as Mivart had done before against Darwin, that numberless characters, if small and insignificant, can never fall within the province of selection. What causes produced the new characters and transformed them while still short of the stage of utility? And as a foundation for the answering of this question we must ask in what manner and according to what laws does this transformation take place? This is what I seek to establish and declare to be the most important task of the present theory of evolution.

Now what does the germinal selection of Weismann furnish for this explanation? Whoever will take the trouble to strip its logic of the dialectic husk in which it is concealed, will find that the demonstration it offers reposes on the suppression of just that stage of evolution which it professes to explain-viz., the extremely important chapter in which on Weismann's own assumption characters are not yet useful and are not yet modified in definite directions.

Yet despite the facts which I have time and again advanced against his doctrine, Weismann has, prior to the enunciation of his 
germinal selection, persisted in retaining this very assumption for all characters. Further, the address of Weismann on germinal selection suppresses the most important feature of orthogenesis, namely, my doctrine of "organic growth," which asserts that transmutation takes place exactly as does the growth of any single individual being, through the transmission of acquired characters, that is, through the given constitution of the animal and the effects of outward influences. It suppresses the important experimental proofs upon which I have taken my stand, and argues only against " inner formative laws" which are postulated for the purpose.

The numerous facts which I have established refute utterly the attempt of Weismann to explain by his new hypothesis of germinal selection the principle of orthogenesis. In a work on Orthogenesis in Butterfies, now in the press, ${ }^{1}$ I continue my attack on Weismann's hypothesis and begin my proof that all the main tenets ${ }^{2}$ of germinal selection repose upon assumptions which are wrong in point of fact and in part even arbitrary.

With regard to the list of works on the subject of orthogenesis which I have given at the conclusion to the "Introduction" to this paper, I have to say that the most fundamental of all is that upon the variation of the wall-lizard. In this work the complete lawconforming orthogenetic variation of a species was shown for the first time, and the proposition put forward that species are essentially nothing else than stages of evolution interrupted at definite points in the developmental path, a standstill, which I have called genepistasis, that is, cessation of transformation on the part of a given kindred or generation (from $\gamma$ ćvos and $\dot{\varepsilon} \pi \imath \sigma \tau \alpha \sigma \imath \varsigma$ ). Further demonstration will be found in my Artbildung und Verwandtschaft bei den Schmetterlingen, ${ }^{3}$ the colored cuts ${ }^{4}$ of which together with

1 Orthogenesis bei Schmetterlingen, Leipsig, Engelmann, I898.

${ }^{2}$ The sentences which appear italicised in the English translation of Germinal Selection.

${ }^{3}$ Jena, Gustav Fischer, I., I889 ; II., 1895.

${ }^{4}$ The cuts in the present pamphlet have, with the kind permission of my publisher, Herr Engelmann of Leipsic, been reproduced from Orthogenesis bei Schmetterlingen, which again are reproductions of the colored plates in my Artbildung und Verwandtschaft bei Schmetterlingen. 
the detailed explanations there given, will render the significance of the facts upon which I take my stand directly intelligible to the eye.

TH. EIMER.

Tuebingen, December, i 897 . 


\section{INTRODUCTION.}

$\mathrm{HE}$ following paper contains the outlines of my views regarding
the process of transmutation in so far as they refer to the facts and laws of definitely directed evolution enunciated by me, and reposes for its proof on the newly furnished facts which just previously to its delivery at the Leyden Congress I had published as the second part of my work Artbildung und Verwandtschaft bei den Schmetterlingen. The address as it was actually delivered has already appeared in the Compte-Rendu des séances du troisième congrès international de zoologie. ${ }^{1}$ In the following pages, too, it has been reproduced substantially as it was delivered. My researches are based on objective truth, and I have therefore no occasion to make subsequent changes in their content. I have only slightly modified the form of the first part of the address by bringing the principal facts and propositions into separate paragraphs and so rendering them more easy of command. Where distinctness required it, I have also made a few changes and additions. The annotations given in the Compte-Rendu have been mostly retained as the immediate expression of defence on my part against an opponent. New notes have been added.

The defence in question will find in the following full substantiation, both material and personal. Of the necessity of such defence one reason must be premised here, apart from what I have said in my "Preliminary Remarks." After having demonstrated during a period of twenty years or more by numerous cogent facts the universal validity of the law of definitely directed evolution,

\footnotetext{
${ }^{1}$ Leyden, E. J. Brill, I896.
} 
and after having shown that this law, and particularly the law of markings enunciated by me, viz., the transformation of longitudinal stripings into spots, cross-stripings, and uniform coloring, held good for the most varied classes and orders of animals, for mollusks, birds, reptiles, mammals, and also in a certain sense for butterflies; after I had repeatedly pointed out the fact that the lawconforming transformation of markings described by me for Papilionidce held true for all butterflies,-Herr August Weismann in a public address delivered at the International Congress of Zoölogists, after recognising some few facts relative to the markings of butterflies, says : " "But I believe we should be very cautious in "deducing laws from these facts, because all the rules traceable in "the markings apply only to small groups of forms and are never "comprehensive nor decisive for the entire class or even for the "single sub-class of diurnal butterflies, in fact, often not so for a "whole genus. All this points to special causes operative only "within this group."

The latter are sorely needed by the champion of omnipotent natural selection to bolster up his doctrine. It is evident, in fact, that he cannot turn conformity to law to any good account whatever for his purpose, but has always had and still has recourse to chance "which constantly holds all possible variations ready at hand" so as to offer at the right time the appropriate selection for the thousands and thousands of varying needs of outward adaptation.

The following will show that every word of the above-quoted sentence of Weismann is also incorrect as regards butterflies, and inasmuch as I have proved the very opposite by numerous facts which are perfectly well known to Herr Weismann, I must further characterise his utterance as having been designedly made for the purpose of prolonging for a brief while the life of his untenable speculations.

It will further appear that the very opposite is true also of the following contention of Herr Weismann :

1 Germinal Selection, p. 6. 
"If internal laws controlled the markings on butterflies' wings, we should expect that some general rule could be established, requiring that the upper and under surfaces of the wings should be alike or that they should be different, or that the fore-wings should be colored the same as or differently from the hind wings, etc. But in reality all possible kinds of combinations occur simultaneously, and no rule holds throughout."

The facts to follow will convince the reader that conformity to law as prevailing between the rear and the fore, the lower and the upper parts of butterflies, is the controlling feature of the transformation of these animals, and that the proposition of the simultaneous presence of all possible combinations, advanced by Weismann for facilitating any and every required adaptation, is entirely groundless. That it is not true is alone demonstrated by the conformity to law which I have proved to prevail in this respect among the Papilionida, and it is at diametrical variance with the requirements of scientific inquiry to make any such bald assertion without having carefully weighed well-known facts and without having carefully examined the salient and patent natural objects which are determinative of the case.

And I must further protest against the "discouraging circumstance that we can assert in scarcely a single actual instance in nature whether an observed variation is useful or not." 1

Our practised dialectician attempts by this exaggerated phrasing of a well-grounded criticism of Darwin's, to repudiate all the countless facts which go to show that the omnipotent natural selection propounded by him is a chimera. The "discouraging circumstance" which the Freiburg zoölogist adduces is rather a selfsaving invention, a way of escape from the narrow corner into which the facts established by me and others regarding definitely directed evolution perforce have driven him. For these facts present an untold number of characters and transformations of characters which in the eyes of every unbiassed person furnish so many unassailable proofs of the absence of all adaptation whatever.

${ }^{1}$ Ibid. See also Die Allmacht der Naturzüchtung. A Reply to Herbert Spencer. Jena, I893, p. 27 et seq. (Also in the Contemporary Review for September, I893.) 
Everything is not adapted. This is proved by the fact that the young, the females, and the aged individuals of animals, are often quite differently marked or colored, and that different species of animals, particularly butterflies, which live either in the same or in the most widely varying outward conditions of life, show, as the case may be, different or similar but accurately determined patterns of marking which can only be attributed to a definite, law-conforming transformation, of which they are the expression. ${ }^{1}$ Fishes ${ }^{2}$ in water, Batrachia, and mollusks in water and on land, reptiles and

${ }^{1}$ Compare also the reasons which are adduced in the address proper, particularly at page 48 .

${ }^{2}$ Fishes particularly show the typical markings in the most pronounced form, and likewise the transformation of the same during their growth. Eels, for example, are longitudinally striped in youth. Acerina Schraitzer, Cobitis fossilis carry these markings their life long. Cobitis barbatula and taenia, Salmonida, Lota vulgaris, etc., are spotted when full grown, Perca fluviatilis, Lucioperca sandra and also the Aspro-species are transversely striped. Pike (Esox lucius) are at first longitudinally striped, then spotted.

Numerous examples are offered by sea fishes, particularly for the transformation of the markings during life.

Young Batrachia, like the Triton-larvæ, are longitudinally striped in the most beautiful manner during youth, and many remain striped or spotted. According to a photograph which I owe to the kindness of Dr. Sobotta of Würtzburg, the longitudinal striping is transformed into spottings also in the young Menobranchus lateralis. Regarding other Amphibia, I have already expressed myself in Variziren der Mauereidechse. In snakes, according to the researches of Jonathan Zenneck (Zeitschr. f. w. Zool. LVIII. Bd. Tiib. zool. Arbeiten I. 2, I894), the earliest stage of marking, viz., the longitudinal striping, is already surmounted and appears from the outset as spots arranged in longitudinal stripes. According to Zenneck the cause of the longitudinal marking is to be discovered in the original arrangement of the blood vessels. H. Simroth and the Countess von Linden assume such relations for mollusks also.

Some time ago (Variiren der Mauereidechse, p. 203 et seq.) I proposed the question as to whether the various stages of markings should not be conceived as adaptations to the plant world which was once more monocotyledonous, and which has suffered change during geological history, but mentioned the objections which militate against such a view. A little book, filled with facts and the corresponding inductions, by A. Sokolowsky, Ueber die Beziehungen zwischen Lebensweise und Zeichnung der Säugetiere, Zürich, I895, seeks to apply this idea to the explanation of the markings of mammals by assuming the cryptogamic plant-world as the original model imitated.

In view of the numerous facts touching this point which have in the meantime been discovered, the assumption of an adaptation of the different forms of markings appears in individual cases both possible and probable, but in the majority as excluded. The markings of fishes in fact militate against such a generalisation. 
mammals, caterpillars, insects, and birds on land and in the air all show the same conformity to law in their markings. In my Variiren der Mauereidechse, page 234 et seq. and also in my Entstehung der Arten, page 72, I have pointed to the fact that also numerous other characters of animals cannot possibly be of any utility. With respect to the shells of snails I proposed the question, "What is " the utility of the general sculpturings, markings, and colorings of "shell snails which during their whole lifetime are usually covered "with mud or dirt and of which the delicate features of marking "and coloring often do not appear until after polishing?" In my Entstehung der Arten, page 38, I said: "If the brilliant mother of "pearl, now completely hidden under the mantel of the inner sur"face of the shells of mollusks, were brilliantly visible on the outer "surface, it would undoubtedly have some utility ascribed to it. "Here belongs also the black and silvery brilliant abdominal skin "of fishes, etc. ... Nothing could be more magnificent than the "play of colors of Labradorite. Is this brilliant display useful to "the stone, and are color and brilliancy generally useful to gold " and countless other minerals? Are they useful to the soap-bub"ble?" I first drew attention to the definite law-conforming transformation of markings in marine shell animals at the Congress of Naturalists at Strassburg in 1885 , and explained the same with the usual appropriate cuts. (Compare Tageblatt, p. 408.) ${ }^{1}$

According to the Tageblatt, Herr Weismann says: "Up to "the present there is nothing in the way of the presumption that "these markings, too, in part at least, repose on adaptations to "the conditions of life." Of what these "adaptations" of mark-

${ }^{1}$ Herr August Weismann, who was present at this meeting, attacked the assumption of internal causes of transformation, saying that even the interesting observations of Eimer afforded no basis for such a supposition-causes which in the sense of Nägeli I never assumed and also did not advocate at Strassburg. I had rather adduced the constitution as determining the fact of development in a few definite directions-but had long previously assumed as the impulse to the transformation outward influences such as climate and nourishment (Lacerta muralis coerulea, Variiren der Mauereidechse), whereas in the case of marine mollusks, Foraminifera, etc., the influence of salt water and definite changes which take place with the lapse of time were said to have probably been co-determinative in the shaping of the sculpturings and the construction of form generally. 
ings might consist which are hidden beneath the epidermis and are not visible from without, he did not then explain, and despite repeated challenges never has explained.

In the meantime my pupil, the Countess Maria von Linden, by her investigations on the sculpturings and markings of marine gastropod shells, ${ }^{1}$ has shown in detail the impossibility of adaptation for these characters, while $\mathrm{H}$. Simroth had previously also advanced proofs of the validity of the universal law of markings for naked snails, ${ }^{2}$ a case in which the demonstrative facts had long ago occurred to $\mathrm{me}^{3}$ while as for the law itself $I$ had declared that to be universal fifteen years ago.

To-day I should like to commend to the attention of "omnipotent natural selection" to explain, if it can, still another fact with regard to mollusks. In the grass at the side of a road near Bordighera, I collected within a circle of a few paces several hundred Helix pisana, among which the Countess von Linden established not less than fifty-three related varieties of markings, depending upon the different manner in which the bands were united or disjoined, as may be seen on a much simpler plan in Helix hortensis and nemoralis. Of what does the selectional value of all fifty-three types consist?" I remember having read somewhere that an English "selection-fanatic" had discovered it in the fact that the striped snails through their resemblance to the grass in which they live enjoyed exemption from the browsing sheep. Could it be because the sheep preferred weeds to grass? Doubtless the explanation will be quite satisfactory to the Freiburg zoölogist after his having recently had recourse to "fictitious" proofs for satiating his selectional needs.

${ }^{1}$ Cf. Countess Maria von Linden, Die Entwickelung der Skulptur und der Zeichnung bei den Gehäuseschnecken des Meeres, Zeitschr. f. wissensch. Zoologie LXI. Bd. (Tübinger Zoolog. Arbeiten Bd. II. Nr. I). Inaug. Diss.

${ }^{2} \mathrm{H}$. Simroth, Versuch einer Naturgeschichte der deutschen Nacktschnecken und ihrer europäischen Verwandten, Zeitschrift fïr wissenschaftliche Zoologie XLII. Bd.

${ }^{3}$ In my Variien der Mauereidechse, p. 204, and in my Entstehung der Arten, I., p. 63, I referred to the longitudinal striping of the young Arion empiricorum, and of other young snails. 
In the meantime the beautiful investigations of Hyatt on Ammonites (Arietidæ) have appeared-researches which give striking examples of orthogenesis and of the non-utility of numerous characters relating to sculpturing. ${ }^{1}$ Further examples on this head may be added here.

Professor Diez of the Gymnasium in Reutlingen has just recently examined in my laboratory the sculpturing of the elytra of Carabida, and here also has established a case of perfect law-conforming orthogenetic transformation proceeding from behind forwards and from below upwards. ${ }^{2}$

If the elytra of other families of beetles were investigated, the same observations would doubtless be made everywhere. For example, I have examined the genus Haltica with regard to these facts -beetles, the various species of which are actually distinguished by these characters, but are extremely difficult to determine for the reason that the characters in question are so delicate that they can be detected only with a microscope and in part reach no development at all. Also the varying coloration of these little beetles is sometimes to be distinguished only by the aid of the microscope. Such is the case, for example, with $H$. euphorbice and $H$. atrovirens, the color of the first of which is given as dark blue, whilst the latter is described as metallic or dark green in color. These beetles are but two millimetres long. The sculpturings of their elytra are also difficult to determine on account of their delicacy; atrovirens is slightly wrinkled and dotted, euphorbia dotted but not wrinkled. The following are a few other characters by which the species are determined : $H$. eruca, marginal border with raised longitudinal fold and inside the latter a groove ; finely scattered dots; elytra at the root much larger than the cervical shield. $H$. consobrina, dots extremely fine and scattered; elytra at the root

${ }^{1}$ A Hyatt, Genesis of the Arietida. Washington, I889. The same, Proceed. Amer. Phil. Soc., Vol. XXXII., No. 143, 1895: The Phylogeny of an Acquired Characteristic.

${ }^{2}$ Compare R. Diez in: Programm des K. Gymnasium in Reutlingen zum Schlusse des Schuljahres 1894-95, Reutl. Buchdruckerei von Ebner und Leib Nachfolger, 1896. The essay in abridged form has recently appeared in the $T u ̈$ binger zoologische Arbeiten. 
considerably broader than the posterior margin of the cervical shield, with rectangularly protruding shoulders, and sharply set off shoulder humps. H. oleracea, finely but distinctly dotted; transverse groove of the cervical shield, deep and almost straight; elytra at the root only slightly broader than the posterior border of the cervical shield.

We are absolutely unable to assign the selective value of all these extremely minute specific marks, which are scarcely visible even with the microscope, nor can we explain from the standpoint of selection why this and numerous other species of beetles, among the Chrysomalids, for example, occur on the same ground-surface now in metallic or gold green colors and now in blue or black, or now in violet.

Haltica eruca, which is commonly blue, also occurs in metallic green, as does also oleracea, while the latter again is sometimes blue. $H$. consobrina stands as regards color usually between blue and metallic green, but does occur separately in either metallic green or blue. $H$. eruce is usually larger than the remaining species, but sometimes occurs small, in which case it is hardly distinguishable from oleracea, etc.

In the varieties of coloring that occur here and in other beetles, as also in the sculpturings, we are concerned with law-conforming definite transformations. In one and the same species of one and the same genus, a certain few variations of coloring only can appear, and not all possible variations. The same holds good, as we shall see, for butterflies, where a definite succession of colorings occurs in the most surprising manner.

With regard to the markings of the genus Zonabris Harold, investigations have been made by Mr. K. Escherich ${ }^{1}$ of Ratisbon, the results of which have been summarised by him as follows :

"I. In the species Zonabris Harold, four main forms of marking are to be observed: (a) Longitudinal striping; $(b)$ spot-markings; $(c)$ transverse striping; (d) sameness of coloring-all of which occur in serial order, the longitudinal strip-

${ }^{1} \mathrm{~K}$. Escherich, Ueber die Gesetzmässigkeit im Abündern der Zeichnung bei Insekten. Deutsche ent. Zeitschrift, 1892, p. 128 , et seq. 
ing being the original marking whence proceed the spot-markings, then the transverse striping, and finally sameness of coloring.

"2. Those species which constitute transitional stages between two of the above named principal forms of marking, are very unstable with regard to markings, whilst those species which represent any one of the four stages in their pure forms are extremely constant with regard to markings. . . .

" 3 . The original marking, the longitudinal striping, is preserved the longest. The changes occur first at the tip of the elytra whence they gradually proceed forwards. ... .

"4. The position of the spots is plainly related to the position of the main tracheal tubes.

"These four conclusions, the outcome of our work with the genus Zonabris, accord perfectly with the results reached by Eimer in his studies of the variation of Lacerta muralis and of butterflies."

Mr. Escherich draws attention to the fact that proposition 2 only (regarding the instability of transitional forms) was not enunciated by me in the above precise form. This is perfectly correct. The fact is extremely remarkable and both deserves and demands explanation. It is not found, however, in the same pronounced form in all animals as it is in certain beetles and other insects and particularly in insects where the metamorphosis is perfect and where the juvenile stages of the markings are entirely effaced. The explanation must be sought in the causes which give rise to the different markings, and in the case of beetles is most probably satisfied by the assumption that the markings are connected with the main tracheal tubes or that they are in connexion with the blood vessels. ${ }^{1}$

${ }^{1} \mathrm{Mr}$. Escherich has treated the whole question of markings and their significance with great ability in his little paper, dealing exhaustively with the constitutional causes of transformation and definite evolution and applying the same to pathological changes which he characterises as reciprocal action between outward influences and the material composition of the animal body. Seeing that the entomologists have understood so well the causes of transformation which I assumed, and grasp so perfectly the significance of the question (for this holds true of other entomologists besides Escherich), the same might naturally be thought of Weismann also, particularly since the views of the early Weismann accorded so perfectly with mine that Escherich placed us peaceably side by side as partisans of the same cause. The subsequent changes of opinion on the part of my opponent were obviously unknown to Escherich, and the juxtaposition of names referred to, in which Nägeli also was included, was hardly less than comical. Escherich supported his opinion upon the views which Weismann uttered in 1868 and 1875 in his 
The facts which Escherich has established for Zonabris may be confirmed in numerous other genera of beetles. At times the species of the same are found nearly or entirely at the stage of longitudinal stripings or that of spottings, or they may have advanced to transversal striping. Most species are very constant in the form of marking reached, others are engaged in transition. ${ }^{1}$

Precisely the same relations as regards markings, viz., the lawconforming transformation of the same, have been recently estab-

work Ueber die Berechtigung der Darwin'schen Theorie and in his Studien zur Descendenzlehre, and consequently points out that all three of us assumed definite evolution on the ground of constitutional causes, and quotes the following words of Weismann from the Descendenztheorie, II., p. II9: "It should not be forgotten "that the products of natural selection depend in the first instance on the varia" tions which the organism in question offers to selection, that the number of pos"sible variations for each species may be very great, but by no means unlimited. "For every species there must also be impossible variations. I am of opinion, ac" cordingly, that the physical nature of every species plays a not less important "rôle in the production of new characters than natural selection, which can only "operate and produce new products by using as its raw material the emanations of "that physical nature, viz., the variations."

It appears plainly from these words of my present antagonist that twenty years ago he was himself the same "embittered opponent of Darwin" that he says I am to-day, and surely the old Herr Weismann owes me his thanks for defending him against the present Weismann, a claim which will find substantiation later. The further fact is also significant that Weismann in his recognition of definite evolution in 1875 both referred to and took his stand upon my "interesting" researches on Lacerta muralis coerulea, which had appeared the year before.

But as Escherich observes, Weismann as contrasted with Nägeli and myself, even then spoke of a large number of definite directions of variation.

I seize the opportunity here to add something further regarding the relation of Nägeli's view to mine. Nägeli, indeed, bases definite evolution on the constitution, which permits transformations in a few directions only and compares it, as I do also, to the origin of definite forms of crystal from a solution (Comp. my Entstehung der Arten I. S. 25). But he assumes no outward influences as the causes of transformation for higher organisms. According to my view outward influences act differently on the constitution of organisms, and so give rise to definite directions of development. What I call "in ward causes" are physico-chemical or physiological causes. The whole transformation is in my view a physiological process, "organic growth." Nägeli, on the other hand, assumes that organisms are by virtue of their varying material composition transformed out of themselves conformably to a "principle of perfection," always advancing and ascending to higher perfection and greater complexity, all of which is produced by internal causes which in his sense are equivalent to the assumption of a vital force-the internal formative laws which Herr Weismann seems to be bent upon ascribing to me. (Compare here my Entstehung der Arten I. S., I6 ff.)

${ }^{1}$ A number of cases are enumerated in the original which are here omitted. 
lished in my laboratory by Mr. H. Sauter of Augsburg for Scutellera.

The markings and the sculpturings of the wings and shells of animals, the markings of the skin generally, of the hairs and the feathers, point to corresponding law-conforming transformative work in the interior of the organism. It is related to this interior as the title of a book is to its contents.

Extremely important facts for my view have been made known also by Mr. Franz Leuthner ${ }^{1}$ for the beetle family of Lucanida.

It appears from his work that the species must have originated by the growing predominance of definite modifications arising according to law as I have shown the case to be for the Papilionida among butterflies.

Here, too, in the formation of species we are concerned essentially with characters that have no special biological significance whatever, and which must be without any utility for the animals; we are concerned, in fact, with the definitely directed evolution of the most widely varying exterior morphological characters.

It was specially shown long ago by Nägeli for plants that precisely the species-forming characters are largely morphological only, and are particularly such as can have nothing to do with utility.

But Darwinism claimed to explain the origin of species and not only the survival of the useful, as is now sometimes said, and the useful, according to its theories, is said to have conditioned this origin with the aid of selection. ${ }^{2}$ The Pseudo-Darwinism of Weismann teaches the omnipotence of natural selection. Its representative is at a loss how to bring the facts here presented into harmony with his views. He therefore passes them over in silence or

\footnotetext{
${ }^{1}$ Franz Leuthner: A Monograph of the Odontolabini, a Subdivision of the Coleopterous Family Lucanida, Transact. Zool. Soc., London, Vol. XI., 1885, p. 385 et seq.

${ }^{2}$ This is a fact, although Darwin himself repeatedly asserts his aim was merely to explain the survival of the fittest. Compare my general introduction to Orthogenesis in Butterflies, which is in course of publication, also the special notes on page 480 .
} 
evades their plain meaning by resorting to the pretext that we are unable to ascertain the selectional value of given characters.

The more we investigate the systematic marks of plant and animal species with respect to utility and orthogenesis, the more shall we be brought face to face on Weismann's view with phases of natural history whose significance we can never explain, while if we adopt my view we shall reach an understanding of the facts and so attain a genuine insight into the phenomena.

I append here a list of my previous works on Orthogenesis-to complete the historical survey of the subject which was given by Weismann $:^{1}$

Zoologische Studien auf Capri. II. Lacerta muralis coerulea, ein Beitrag zur Darwinischen Lehre. Leipzig, Engelmann, 1874.

Ueber das Variiren der Mauereidechse, ein Beitrag zur Theorie von der Entwicklung aus konstitutionellen Ursachen, sowie zum Darwinismus. Archiv für Naturgeschichte und selbständig. Berlin, Nikolai, r88I.

Ueber die Zeichnung der Tiere. I. Säugetiere. A. Raubtiere. Zoologischer Anzeiger, 1882 und $188_{3}-84$.

Ueber die Zeichnung der Vögel und Säugetiere. Jahreshefte des Vereins für vaterländische Naturkunde in Württemberg, I883.

Bruchstücke aus Eidechsenstudien, Humboldt, I883.

Ueber die Zeichnung der Tiere I-VI, Humboldt, I885-88.

Ueber die Zeichnung der Vogelfedern, Humboldt, I 887.

Entstehung der Arten I, Jena, I888.

Die Artbildung und Verwandtschaft bei den Schmetterlingen. I. Eine systematische Darstellung der Abänderungen, Abarten und Arten der segelfalterähnlichen Formen der Gattung Papilio. Jena, G. Fischer, I889.

Die Verwandtschaftsbeziehungen der Raubsäugetiere, Humboldt, I89o.

Bemerkungen zu dem Aufsatz von A. Spuler, Zur Stammesgeschichte der $\mathrm{Pa}$ pilioniden, nebst einem Zusatz: Ueber Thatsachen in Fragen der Entwickelungslehre. Zoolog. Jahrbücher. Abt. für Systematik. . Bd. VII., I893.

Ueber die Artbildung und Verwand tschaft bei den Schmetterlingen. II. Eine systematische Darstellung der Abänderungen, Abarten und Arten der schwalbenschwanzähnlichen Formen der Gattung Papilio. Unter Mitwirkung von Dr. K. Fickert. Jena, G. Fischer, I 895.

Ueber die Artbildung und Verwandtschaft bei den schwalbenschwanzartigen Schmetterlingen. Vortrag. Verh. der deutschen zoolog. Gesellschaft zu Strassburg i. E., 1895 .

Ueber den Begriff des tierischen Individuum, Rede, gehalten a. d. Vers. d. Naturforscher zu Freiburg i. B., I883, abgedruckt in Entstehung der Arten.

${ }^{1}$ Compare Germinal Selection, Appendix, where Weismann gives a sketch of the history of definite variation. 


\section{THE LEYDEN ADDRESS.}

THE all-indispensable requisite for deciding questions of evolu1 tion, and particularly those of the origin of species, is a full and accurate knowledge of the characters of species, a full and accurate knowledge of their modifications-their aberrations and their variations.

I have held this principle for years as the starting-point of my investigations, in opposition to the movement which has to-day come into the forefront of scientific notice, which assumes an alien attitude towards animals and plants in their entirety, and which by a neglect of facts generally has led to the uttermost bounds of speculative extravagance.

While engaged in establishing the facts involved, I reached my evolutionary theory of the organic growth of the animate world (organophysis or morphophysis) as I have propounded it in my work Entstehung der Arten auf Grund von Vererben erworbener Eigenschaften nach den Gesetzen organischen Wachsens. ${ }^{1}$

The propositions which I advanced in this work regarding the causes that underlie the transmutation of the animate world, and regarding the causes effecting the segregation of organisms into species, have been fully confirmed by the investigations which I have since undertaken, and I have nothing to retract. I have not yet published the second part of the work for the reason that I was desirous of establishing additional facts in corroboration of my views. ${ }^{2}$

${ }^{1}$ English translation, Organic Evolution, London, I889.

${ }^{2}$ Besides, public opinion has been dominated for a considerable period by that exaggerated Darwinism which stands for the omnipotence of natural selection, and 
These researches which I have been pursuing for six years are now in course of publication, and one of them is the second part of my Artbildung und Vervoandtschaft bei den Schmetterlingen which has recently appeared and which I desire to lay at the foundation of my present address.

Organic growth, organophysis or morphophysis, is expressed in definitely directed evolution, orthogenesis, ${ }^{1}$ according to the manner in which the transmutation, the general transformation of forms, takes place. I am concerned in this paper with definitely directed evolution as the cause of transmutation, and not with the effects of the use and activity of organs which with Lamarck I adopted as the second main explanatory cause thereof, as the title of my above-mentioned book shows. In both cases transmutation rests on the inheritance of acquired characters.

With the question regarding (a) the causes of transformation, is associated accordingly the question regarding (b) the causes of the segregation of chains of organisms into species.

My paper, therefore, falls into two parts.

which from its monstrosities has been aptly termed Pseudo-Darwinism. Its champion, Herr August Weismann, has deemed it expedient to ignore utterly my labors, and to suppress all mention of the telling arguments of fact which they contained and which were subversive of his opinion. He took the same attitude with regard to the results and outcome of that portion of my researches on Butterflies which I published in I889. But it was at the same time evident that he gave them searching consideration since in every subsequent publication he has altered his views in accordance with mine, and that in essentially fundamental problems. It was my obvious policy, therefore, to hold back my new publication until this transformative process had been completed to my full satisfaction, as has now actually been done in Weismann's sudden and unexpected recognition of useless characters and of orthogenesis.

${ }^{1}$ The translation of definitely directed development (bestimmt gerichtete Entwicklung) into the word "orthogenesis" was first employed by Wilhelm Haacke in his book Gestaltung und Vererbung in 1893 , and as it is very expressive, I have adopted it for my own use. Contrary to my usual custom, I have been obliged to use many other words of Greek origin, and even some extremely uneuphonious ones. But experience shows that such technical terms are indispensable in establishing and disseminating exact ideas. 


\section{DEFINITELY DIRECTED EVOLUTION OR ORTHOGENESIS.}

The proof for orthogenesis, - or the fact that the transmutation of the animate world takes place, not as Darwinism and the advocates of "omnipotent natural selection" (Weismannian PseudoDarwinism) assume, accidentally in numerous and even widely diverse directions, but systematically and conformably to law in only a few directions-was furnished by me in my works on the variations of animals years ago. It is my property which no one can dispute me, and I am emphatically obliged to protest against Weismann's having suppressed my name in his discussion of definitely directed evolution while citing those of Nägeli and Askenasy. Nägeli's definitely directed evolution was a purely theoretical assumption, having been based on his equally theoretical and unfounded hypothesis of a principle of perfection. With the principle of perfection Nägeli's whole doctrine falls to the ground. My own conception had originally nothing to do with it. For my researches show that I reached the principle of orthogenesis and its demonstration quite independently by the study of modifications in their minutest initial details, primarily with regard to the markings of animals. In the domain of zoölogy no one but I ever sought to advocate $^{1}$ or verify orthogenesis as a law, or even to recognise or assume it as a dominant factor in evolution. ${ }^{2}$

${ }^{1}$ One very important law, which may be classified under orthogenesis, was really enunciated earlier, namely, the law of retrogressive transmission of characters, corresponding to my undulatory law, which was advanced by Cope, Würtenberger, Hyatt (Ammonites). See infra, "Kymatogenesis."

${ }^{2}$ Even Askenasy, in his essay Beiträge zur Kritik der Darwin'schen Lehre, an important book too little noticed, did not give a full demonstration of the definitely directed variations of plants as based on the facts. At page 7 he says merely that the blossoms do not appear in the most varied but only in certain definite colors, for example, a blue rose or a blue lily of the valley has never yet been found. It is the same with the variation of the shapes of leaves and blossoms. Whereas many plants with non-indented leaves most frequently produce varieties with more or less divided leaves, in the case of other flowers divided leaves are unheard of. No one would expect grass to produce a variety with divided leaves. As for the rest Askenasy takes his stand on the basis of Nägeli's principle of perfection, and his treatise is an elaboration of the hypothesis of this investigator. 
Orthogenesis is a universal law. It holds, as I have long insisted, not only for the markings but also for the other morphological characters of animals, as also for those of plants. Even in the latter, as my personal observation has convinced me, the markings of the blossoms and the shape of the leaves follow, in rigorous conformity to law, a fere definite directions.

The law of definitely directed evolution or orthogenesis, not that of natural selection, dominates in its entirety the transformation of the animate world (leaving out of consideration here the effects of use and disuse). The fact that the variations of living beings follow in perfect conformity to law a few definite directions and do not take place accidentally in the most diverse or in all possible directions, alone shatters irreparably the foundation of the Darwinian doctrine. For Darwin's doctrine must always have a most varied assortment of variations ready at hand if selection is to play a determinative part in the production of forms; and, being a necessary presupposition of the doctrine, this assumption of the constant presence of all possible characters is always asserted as a fact by the champions of omnipotent natural selection.

But if only a few definite tendencies of evolution predominate then they shape the organic world, and there is left for selection only a very subordinate task. This has already been stated by Nägeli and Askenasy.

I must, in fact, reiterate again and again that natural selection can under no circumstances create anything new. It can only work with existing material, and it cannot even use that until it has attained a certain perfection, until it is already useful. Selection can only remove what is downright injurious, and preserve what is useful. By always selecting the useful it will strengthen its development, but the facts prove that even this can take place only in a restricted measure. ${ }^{1}$ Primarily, therefore, the importance of selection consists not in its being an active and principal agency in the transmutation of forms but in its being at most a simple collateral instrument in this process, entirely subordinate to orthogenesis.

${ }^{1}$ But its effects will become distinctly efficient when utility coincides with the given direction of development. 
The causes of definitely directed evolution are contained, according to my view, in the effects produced by outward circumstances and influences such as climate and nutrition upon the constitution of a given organism. This is not Lamarckism, for Lamarck ascribed no efficiency whatever to the effects of outward influences on the animal body and very little to their effects upon vegetable organisms - a point which is constantly mistaken and incorrectly repeated, even by Weismann in his recent Germinal Selection. ${ }^{1}$

In my view development can take place in only a few directions because the constitution, the material composition of the body, necessarily determines such directions and prevents indiscriminate modification.

But through the agency of outward influences the constitution must gradually get changed. The organisms will thus acquire more and more physiological individuality and respond to outward influences more and more in a manner harmonising with their specific individuality-and so new directions of development will be produced.

Now, in this influencing of the direction of evolution by the constitution of organisms, in this specific physiological individuality of organisms, we have the so-called inward causes of transmutation, which plainly have nothing to do with the causes assumed by Nägeli nor with his principle of perfection. ${ }^{2}$

The potency of the direct action of outward circumstances can no longer be disputed now, since Standfuss and others by subjecting the pupæ of butterflies to heat and cold have obtained almost exactly the same varieties of butterflies that are found as warm and cold forms in nature, and since Standfuss has produced varieties which correspond almost perfectly to the species whose origin, ac-

${ }^{1}$ Darwin entertained the same error and the misconception has been perpetuated despite Quatrefages's having thoroughly overthrown it in his treatise Darwin et ses précurseurs franf̧ais.

${ }^{2}$ Physiological individuality is changed even by the age of the organism or of its tissues. Senile tissues may alone produce new forms, as is proved by the developing without great activity of new bones, for example in the concha of mammals. 
cording to my researches, is, from their geographic occurrence, to be ascribed unquestionably to climatic causes. The potency of outward influences is further proved by the experiments of Schmankewitsch with Artemia salina, as well as by the artificial production of Amblystoma from Siredon pisciformis, and the retardation of the development of Tritons by the withdrawal of water or air, and in connexion with this further by all the members of the group of Amphibia.

Now these are all incontrovertible proofs of the inheritance of acquired characters.

The outward and inward causes above named, which in my view determine the transmutation of the organic world in a few definite directions, are operative simply by being causes of growth. The same causes have conditioned and still condition individual growth that have conditioned the transmutation or transformation of the organic world. Hence my explaining the latter as organic growth (organophysis or morphophysis).

The organic world has accordingly taken form through the stress of outward circumstances, and it persists only by the continuance of the action of these outward influences. If they fall away we have death.

Organic growth, in direct contradiction of Nägeli's view, rests not always on perfection but frequently on simplification or retrogression. And even this simplification reposes according to my definitions on growth.

The directions of evolution have nothing to do with utility. They produce forms without the least regard thereto by starting with very small and scarcely visible beginnings and reaching with personal and phyletic age greater and greater maturity. The facts established by myself and others prove unqualifiedly that by far the greater number of characters so arising never fall within the province of utility. They prove that numberless characters are produced in living beings which are not useful at all, and that hence there can be no question at all of an "omnipotence of natural selection."

Inasmuch, therefore, as the directions of evolution have noth- 
ing to do whatever with utility, and inasmuch as they are few in number only, the constantly reiterated assertion that selection always finds all possible characters ready at hand from which the useful can be chosen, preserved, and selectively fostered, falls completely to the ground.

For the same reason the proposition is also unfounded that the directions of development themselves are selected-a proposition whereby the champion of "omnipotent natural selection" has sought to render innocuous the incontrovertible facts of orthogenesis which for good reasons he has so long neglected. The directions of evolution cannot possibly be selected, for the reason that from the outset they have nothing whatever to do with utility.

That everything that exists is not useful, and that still less all orthogenetically directed things have utility, is proved by my researches on the markings of animals, where I have shed great light on the minute and originally almost invisible rudiments of characters which, even in their subsequent development as marks distinguishing varieties and species, appear quite useless for the struggle for existence.

At variance with all the facts of definitely directed evolution established by me and others, and hence entirely unfounded, is also the contention of my opponent, ${ }^{1}$ made in connexion with an appeal to Galton and others, that the variations demonstrably oscillate to and fro in the most diverse directions about a given zeropoint. There is no oscillation in the directions of development, but simply an advance forwards in a straight line with occasional lateral divergences whereby the forkings of the ancestral tree are produced. ${ }^{2}$

${ }^{1}$ Germinal Selection, p. 20.

${ }^{2}$ In my Entstehung der Arten I have ascribed these forkings among other causes to the fact that direct outward influences varying in different localities act upon every stage of development and may deflect subsequent development away from the original line, and that through long persistence in the same conditions, and by the uninterrupted continuance of the same influences, an organism will after many generations, as a result of constitutional impregnation (conservative adaptation) become differently constituted in composition and so behave differently towards the outer world from what it did before. It is plain that the very persistence of the comparatively simple forkings of the ancestral tree of animals and 
In his printed address Herr Weismann has substituted for the word "oscillation," which he used in his oral address, the phrase "fluctuation of variations about a mean" or about a "zero-point."

In saying, as I did above, that no such fluctuation takes place but advancement only, it will perhaps be objected that I have forgotten reversion. But $I$ take reversion to be a halting at earlier stages of evolution. On the other hand, it is true that there exists a retrogression or retrogade growth of characters in connexion with disuse (compensation). But I have also brought this retrogression under the concept of organic growth. Unquestionably we have here again in a certain measure an advance to more definite though simpler formation, but no directions of development, for the latter have primarily nothing to do with use and disuse, but simply with their weakening or strengthening.

Now these three propositions, - namely, that selection always finds all possible variations at hand from which to choose the useful, that the directions of development are selected, and that the variations demonstrably oscillate to and fro about a zeropoint, - these three propositions have, without any mention of my works which positively disprove them, been advanced by Herr August Weismann in his recent address as the foundation of conclusions which, culminating in his so-called germinal selection, press definitely directed evolution into place among his hypotheses or at least force it into agreement with them,- - which was his object. But as the premises were false, self-evidently everything based upon them falls to the ground. Furthermore, oscillation would annul all conformity to law in definitely directed development. But

plants proves the potency of definitely directed, and not of oscillating, development in the formation of the living world. If the countless demands of adaptation, which, owing to their multiplicity cannot be systematised, were determinative of the process, no such simple, unified, natural system based on forked ramifications would exist, but we should have a disordered jumble of species produced under the stress of any and every sort of adaptive requirement. As Nägeli has said in his Entstehung und Begriff der naturhistorischen Art (München, 1865, p. 26): "If variation took place uniformly in all directions, we should necessarily also " have descending and horizontal lines of affinity as well as such as converge from " two different starting-points. Relationship could then not be represented as ar-

"borescent ramification." 
oscillation is positively indispensable to the advocacy of omnipotent natural selection, otherwise there is no upholding the proposition that selection has an abundance of variations constantly at its disposal-a proposition which, as already said, has been demonstrated to be perfectly groundless by the facts which I have established of the actual existence of orthogenesis.

The facts of orthogenesis find expression in laws of evolution, which were first worked out by me with reference to markings but are also perfectly applicable to morphological characters. We are concerned here with actual laws of evolution, for, as is growing daily more apparent, all the discoverable relevant facts follow without exception the same rule. ${ }^{1}$

The laws set up by me are as follows :

I. The universal law of markings (universal law of transmutation). (Transmutation of longitudinal striping into spots, crossstriping, and uniform coloring.)

2. The postero-anterior and supero-inferior or infero-superior development, so called by me from the character of the local transformation of the markings. This finds expression in the fact that the new markings appear on the body of the animal from behind forwards and from above downwards, or conversely, whilst the old ones disappear in the same direction and succession. This definitely directed local transformation, like most of the other laws, holds true also for the other morphological characters of the body covering, for example, for the sculpturing of the shells of mollusks, and the elytra of beetles.

These facts might perhaps be appropriately classed under

${ }^{1}$ Herr Weismann in his recent address, without mentioning my name but plainly referring to me, has spoken of "so-called laws of evolution"-and not without reason, for the conformity to law which I have established here is tantamount to nothing less than a full matter of fact refutation of his hypotheses. Furthermore, the physicist and physiologist dispute the right of biologists to speak of "laws." I believe, however, that we are justified in speaking of laws when treating of a sum-total of facts which take place without exception according to a rigorous rule, even though we cannot see or calculate the causes of the phenomenon. Since Herr Weismann himself has formerly spoken of development conformably to law, his animadversion cannot be based upon this objection. 
some one single and universal expression, by enunciating a law of definitely directed local transformation or topo-orthogenesis, upon which further the law of undulatory evolution or kymatogenesis reposes.

3. The law of male preponderance-the fact that the male is ordinarily a step or so in advance of the female in expressing the direction of development, and then transmits in a certain measure his characters to the species.

But as I have recently shown in the case of butterflies, there also occurs by way of exception:

4. Female preponderance.

5. The law of preponderance of age, ${ }^{1}$ the fact that new characters appear first in personal age or rather in the time of greatest expansion of power (and most commonly in the old males, e. g., the wall-lizard) and in phyletic age (e. g., Ammonites).

6. The law of undulatory development, or kymatogenesis, the fact that during the ontogenetic and phylogenetic growth of the individual a succession of transformations, each following the other, runs along over the body of the animal in a definite direction. ${ }^{2}$ To this is added :

7. The law of independent similarity of development, or homoögenesis, which states that the same directions of evolution may be operative in different and not immediately related forms, and may lead to quite similar morphological results. ${ }^{3}$

8. The law of differently graduated development, or heterepista-

\footnotetext{
${ }^{1}$ Not contained in the Compte-Rendu, but long ago propounded by me in my Mauereidechse.

${ }^{2}$ This law of undulation, as already remarked, was first observed by Würtemberger, Cope, and Hyatt with reference to the morphological characters of the shells of Cephalopoda. Hyatt characterises it as a law of acceleration, probably because the old characters, and the older the faster, are both ontogenetically and phylogenetically displaced on the organism by new characters tending in definite directions.

I believe that the name kymatogenesis or undulatory evolution best characterises all the phenomena of the process, although it, too, has its drawbacks. It can best be represented to the eye by the rise and disappearance of the series of waves caused by the dropping of a stone in a smooth pool of water.

${ }^{3}$ Afterwards demonstrated by Hyatt in the Arietidce as morphological equivalents, and supported by examples from the shells of Cephalopoda.
} 
sis, the fact that different characters may develop in the same organism in different degrees and in different directions.

9. The law of unilateral development, or of amiktogenesis, the fact that as a rule the progeny arising from the sexual mingling of two different parents are not a perfectly uniform mixture of the two parts, but lean more to one side or more to the other. ${ }^{1}$

Iо. The law of reversal of development, or epistrephogenesis, the fact that directions of evolution may get reversed and turned back to their starting-point, as I recently observed in the case of Foraminifera, and as doubtless Hilgendorf's Planorbis multiformis proves, and as Hyatt has demonstrated for the shells of Cephalopoda. ${ }^{2}$

I I. The universal law of persistence or of standstill of evolution, epistasis, the fact that evolution may often long remain at a standstill at a definite stage.

These and other laws, which I shall revert to later, will receive their establishment, so far as that has not already been done by me, in works now in course of publication. For some of the most important the proofs may be drawn, as we shall see, from my work on Die Artbildung und Verwandtschaft bei den Schmetterlingen. The laws hitherto mentioned which refer to transmutation generally show that evolution is everywhere a definitely directed process, and, excepting rare cases of reversion probably occurring in the lowest forms of life, is one which advances steadily forward as if in conformity to a definite plan, in diametrical contradiction to the assertion that variations "oscillate in the most diverse directions about a zero-point."

With the proof that the directions of evolution are totally independent of utility, the doctrine of the dominance of selection in transmutation and the doctrine of the omnipotence of natural selection is totally refuted. In place of the latter appear as determinative factors orthogenesis and morphophysis; and hence follows the impotence of Darwin's selection in the transformation

1 Militates against the import of Weismann's amphimixis.

${ }^{2}$ Here belongs Hyatt's "acceleration in degeneration." 
of vegetable and animal forms, with the express restriction that selection in selecting what is useful can strengthen the development of the same and that the development will be greatly advanced as soon as a given direction of evolution coincides with utility. Selection is therefore not a principal instrument of transmutation; it is at most a collateral instrument. How far it really can be effectual in the latter sense in preserving the existing forms of the world, must, after definitely directed development has been established as the principal means at work, be shown anew by unprejudiced and fresh investigations. But it is beyond doubt that selection can be proved devoid of all importance for by far the majority of those characters which are distinctive of the species, and the same for the specific marks of entire groups of animals. It is my task, now, to adduce this proof for such a group of animals, namely, for the Papilionida, according to investigations which I have published regarding species-formation and relationship among the butterflies. I thus come to the second part of my paper.

SPECIES-FORMATION, OR THE SEGREGATION OF THE CHAIN OF LIVING ORGANISMS INTO SPECIES.

The Darwinian theory of selection furnishes no explanation whatever of the formation of species. It contents itself with the bare assumption that intermediate forms perish because the newly originated, more perfectly adapted forms displant the old and less perfectly adapted ones. The indisputable objections which have been raised against this explanation are well known. Where the transformation is very gradual, as it is in the great majority of cases, the elimination of the intermediate forms, particularly if the modification affects only single individuals, is, owing to sexual intermingling, quite impossible without accompanying separation in space. But, as I have shown in the case of butterflies (e.g., Papilio Telesilaus), new species do originate in the very heart of the distributional area of ancestral forms, and new species have unquestionably arisen everywhere, if not among yet alongside one another, without separation in space.

Darwin's selection cannot explain the transmutation of forms, 
nor the origin of new characters in forms; and no more can it explain the origin of species, despite the title of his celebrated book.

The origin of species can be traced to three main causes: (I) genepistasis, (2) halmatogenesis, (3) kyesamechania, all of which will receive their explanation in the following.

(I) By genepistasis, or cessation of development, I understand the halting of single forms at definite stages in the path of development whilst others move onward. Epistasis, the persistence or standstill of evolution at definite stages, is the main determining cause of the formation of species. It is solely through the operation of this cause that species are everywhere enabled to originate without separation in space. For orthogenesis, i. e., definitely directed and law-conforming evolution, produces the simultaneous transmutation of numerous individuals of the same species. And when a large number of individuals thus push onward in their developmental path whilst others remain behind, unavoidably a new species must originate. The evolutionary advancement of a large number of individuals can, therefore, take place in the very heart of the distributional area of the species, provided the advancing individuals are more sensitive than their fellows to the outward influences that condition the transmutation. But the farther the influences under consideration, viz., climatic and nutritional conditions, are removed from the centre of the distributional area of a species, the more powerful is their transformative effect. And the facts of variation for any given species do really show more aberrations and varieties as we recede from the centre of its distributional area, while still farther away new species are observed.

But, conformably to the law of heterepistasis, or the cessation of development at different stages, single characters may in transforming suffer suspension at a lower stage of development whilst others continue to advance. Heterepistasis appears to me a means of high import for insuring the stability of perfected species and one which is more determinative the higher and more complex the organism is. The interaction and interconnexion of so many widely diverse characters in their capacity as a totality is bound to insure the permanence of the whole for the reason that the characters in 
question must necessarily counterbalance each other, seeing that by the very reason of their union as a whole each could not well be transformed by itself, just as in the pendulum of a standard clock the bars of different materials compensate each other during expansion and contraction.

On the other hand, simple organisms, in which few tendencies of development are as yet active, will give rise to less pronounced species, since here the developmental tendencies may even become reversed (Foraminifera).

But epistasis, or persistency of evolution at definite stages, is of paramount importance for the origin of species and varieties in the further respect that any individual characters whatever may in the course of enormously long periods of time make their reappearance by way of "reversion" as specific characters. For example, in the plumage of birds there sometimes reappear as specific characters markings which were specific characters in far distant and not at all immediately related ancestors or which only occurred in the down of such ancestors. We are concerned here, accordingly, not with ordinary reversion, which is an occasional phenomenon only and has nothing to do with the characterisation of new species, but with permanent reversion, with permanent phyletic reversion.

At times such old characteristics reappear only in one sex, particularly in the male, when we have permanent male phyletic reversion. Occasionally they appear only in some one part of the covering, for instance, in the ornamental part, or during transformation in the transitional part, when we have metamorphic or transformative reversion.

Such permanent reversion is to be conceived as epistasis or persistence, because the character in question, being according to the biogenetic law subject to repetition during individual development as an inheritance from ancestors, but being only fugitively repeated in the immediate progenitors of the retrogressive species and never making its appearance at all in the adult individuals, this character, we say, persists and makes its appearance as a distinctive mark of the perfected species.

The explanation of ordinary reversion or atavism, personal 
or individual reversion, is implicitly involved in the foregoing. There is concerned here merely the persistence or permanence of single characters, which according to the biogenetic law were obliged to appear only evanescently during ontogenesis, thereafter making way for others. ${ }^{1}$

Atavism is thus naturally classified with the remaining laws of persistence enunciated by me and is explained by them and the biogenetic law jointly. It is simply heterepistatic, ontogenetic, personal cessation of development.

Likewise permanent phyletic reversion is heterepistatic cessation of development-not ontogenetic but phylogenetic. We may characterise the two species of reversion most simply as ontogenetic and as phylogenetic reversion, or as ontogenetic and phylogenetic epistasis or heterepistasis. Both differ from the species-originating process known as genepistasis by the fact that genepistasis signifies a cessation of all the characters embraced by a given definite direction of evolution, the arrestation lying entirely outside of ontogenesis. We enter here again the domain of orthogenesis to which both ontogenetic and phylogenetic reversion ultimately belong.

The biogenetic law, ${ }^{2}$ also, is the expression of definite directions of evolution in so far as these have not been altered by the use or disuse of organs in ancestors. Naturally it holds good not only for ontogeny but also for metamorphosis or the period of development persisting after birth or after emergence from the egg. We see here, for example, in the markings of lizards, how one marking is replaced by another in the direction from behind forwards (postero-anterior development, law of undulation), and how the females usually preserve the youthful characters longest or for good, whilst the males first assume new characters (male preponderance). Male

${ }^{1}$ Compare H. Kohlwey, Das Gesetz der Vererbung, Blätter für Geflügel$z u c h t, 1886$, where the same idea is uttered.

${ }^{2}$ Hyatt is of opinion that the biogenetic law was discovered not by Haeckel but by Agassiz. As a matter of fact, it had been previously clearly and definitely enunciated by Kielmeyer, Mechel, and other Germans. Compare also Schopenhauer, Parerga, II., p. I68. 
preponderance is simply the advance of the male one evolutionary step further along the path of orthogenesis. In numerous animals investigated by me, the old original characters are found permanently at the front in a fully perfected state, whilst the new ones are found at the rear; as in the markings of lizards, of birds of prey, Papilionidæ, etc. In the sculpturing of ammonites and snail shells the old characters are found on the most primitive whorls, the new characters on the whorls that appear latest.

Perfectly analogous examples may be adduced for plants with respect to the succession of leaves.

A second important cause of the segregation of the natural chain of organisms into species is :

2. Saltatory development or halmatogenesis, which consists of the sudden, unsolicited appearance of new characters, or, where a large number of such new characters appear, of the sudden origin of new forms that deviate widely from the ancestral form. To what extent direct outward influences are operative here is demonstrated by many facts, such as the sudden, kaleidoscopic transmutations of the markings and colorings of butterflies through the agency of heat or cold during development (including horadimorphism or seasonal aberration), the sudden transmutations due to nutrition or general outward conditions of life, as those determinative of the origin of Amblystoma. So, too, the conversion of Artemia salina into Branchipus (Schmankewitsch) shows sudden, graded transmutations. Everywhere here correlation appears as one of the most effective causes of the transmutation of forms. ${ }^{1}$

That separation in space is an influential factor in the origin of species follows immediately from my doctrine of the genepistatic formation of species, and from the effect of outward influences upon transmutation.

Outward influences in their action on genepistatically segregating forms are enhanced as to species-creating power, or as to their power of promoting the creation of species, according as

${ }^{1} \mathrm{~A}$ distinction is to be made between the kaleidoscopic correlation which is here operative and the functional correlation of Cuvier which relates to the use of parts 
separation in space keeps the originating species and the ancestral species absolutely apart, or absolutely prevents sexual intermingling. But no direct, independent significance can be accorded to separation in space as a factor in the formation of species.

As already said, the formation of species may take place in the very heart of the distributional area of the ancestral form, and so be conditioned solely by genepistasis.

Of the highest significance for the formation of species without separation in space, however, is the following factor:

3. Kyesamechania, ${ }^{1}$ or hindrance to impregnation, the inability of a certain group of individuals to impregnate others than themselves, due to morphological or physiological changes in the seed or ovum or both, or to a change in the time of maturity of the seeds or ova. Changes of this kind occur mainly through correlation, through indirect influence on the sexual organs.

I referred to the phenomenon of prevention of impregnation as early as $1874 .{ }^{2}$ Some time later (I886) George J. Romanes lighted upon the same idea and under the name of physiological selection contrasted prevention of impregnation as a factor in evolution with the origin of species by natural selection. ${ }^{3}$

The main factor, finally, that conditions and promotes the formation of species is the activity, the continued use of certain organs. The same result may be obtained by intercrossing, though ordi-

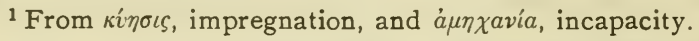

${ }^{2}$ First in Zoologische Studien auf Capri. II. Lacerta muralis coerulea, Leipzig, Engelmann, I874, p. 45. Then in Zoolog. Unters. mit bes. Berücks. d. Biologie, I. üb. Bau u. Bewegung d. Samenfaden, Würzb., Stahel, 1874, p. 42, and Wïrzb. Verh., 1874. Also in Variiern d. Mauereidechse, 1881, p. 257, and in Entstehung d. Arten, I., p. 45. In prevention of impregnation there are concerned, according to my opinion, the two following factors: (I) mechanical causes, involving (not to mention such as are founded in the rough structure of the sexual organs) (a) the size of the spermatozoa or the breadth of the oviducts or the varying stoutness of the integuments of the ova, and (b) the varying power and form of movement of the spermatozoa which according to my observation is in vertebrates performed in screw-like motions mostly rotatory. The spermatozoa are, in fact, in closely allied species widely different as to shape and movement. (2) Physicochemical differences in the composition of sperm and ovum.

${ }^{3}$ Journal of the Linnean Society. Zoölogy, London, I886. The Monist, Vol. I., No. I. 
narily this has a levelling and hindering effect in the formation of species.

As for the rest, species are not originated by natural selection but already existing species are preserved by natural selection.

I accept in this unreservedly one part of Darwin's conceptions, as it is stated in the inscription of his book on the origin of species which reads: "The origin of species by means of natural selection, or, the preservation of favored races in the struggle for life."

\section{DEMONSTRATION.}

I shall extract the proofs for the views which I have here enunciated, from the facts furnished in my Formation of Species and the Relationship of Butterfies, as found in the recently published second part of this work, containing "the forms allied to the Swallowtails."

I distinguish between three groups of Swallowtails: the Turnus, Machaon, and Asterias groups. These groups contain mostly American forms and preponderantly North American forms. Alexanor alone in the Turnus group occurs in Europe and Asia; the Machaon group is represented in Europe, North America, Asia, and Africa. Further, all three live in connected distributional areas and are also all three immediately connected in relationship. The North American Papilio Eurymedon belonging to the Turnus group, or some similar ancestral form of this same group, forms the starting-point of all the others and at the same time connects them with the Segelfalter (Papilio podalirius). The relationships involved are mainly inferred from the markings, but the other characters all follow these: venation does not appear to be entirely determinative of the markings. We can tell from the markings, coloration, and shape at once that relationship follows geographical distribution, the fact being that at every remove from the main seat of the phyletic types no matter how small, the forms represent more and more distantly related varieties or species. As we have already demonstrated in the case of the Segelfalter, so also in the case of the Swallowtails, as a glance at the Plates of the last-named work will show, variations of individuals pass in adjacent areas into aberrations, and in more remote areas into species. The same Plates 
(Swallowtails) also show that everywhere definite directions of development are determinative of the transmutation. By them are produced, first individual modifications in single forms of a species (aberrations), then varieties, and finally again, species. Now all these directions of development which lead to the origin of aberrations, varieties, and species, have nothing to do with origin by natural selection, nor with sexual selection. The new forms arise without the least regard for utility; every new form of butterfly shows for itself the absolute impotence of natural selection. On the other hand, the facts of geographical distribution with respect to relationship show very distinctly that outward and especially climatic conditions must have been coincidently determinative in the formation of species. This is proved by the fact that artificial temperatures produce exactly the same directions of development or modifications thereof as the same butterflies exhibit in their actual geographical distribution. This has been recently shown with perfect clearness by the researches of Standfuss, who by causing heat to act on the pupæ of Papilio Machaon in Zürich, produced butterflies such as are found in August in Syria. And here not only changes of coloration and marking but also those of shape as produced by heat in the pupæ agree with the southern forms.

Additional proof of the correctness of my view is furnished by the facts of seasonal aberration, and first by the fact that the summer forms everywhere correspond to the forms artificially produced by heat, and secondly by the fact that the characters of the summer forms of species living farther towards the North are the same as, or closely similar to, the distinguishing characters of allied butterflies which live in the South. ${ }^{1}$

The experiments of Standfuss, Merrifield, and Fischer, as well as the facts which seasonal aberration furnish, show that the explanation which Weismann has advanced regarding the origin of Vanessa Levana being a reversion cannot hold water, that this is also true of his explanation of the origin of the dark form of

\footnotetext{
${ }^{1}$ Compare especially the first part of my Schmetterlinge, Sec. "Die Segelfalterähnlichen."
} 
Polyommatus Phlaas, and finally that in all the consequences of the action of heat and light on butterflies we are concerned simply with the inheritance of acquired characters, which it was his special object to overthrow.

"On the plates of my butterflies the formation of species and the laws of evolution can be read directly from the wings. The markings and colorings of the same are so many letters speaking a clear and forcible language that no one who wants to know the truth can misunderstand. Like the leaves of an open book the written characters on the wings of our butterflies show their past and present history."

"Here on the tablets of the laws which living nature has placed in our hands, the truth of evolution lies written, and not in the writings of the naturalist philosophers who dream their evolutionary fancies with an utter disregard of the facts, and who scatter them among their credulous followers in unremitting profusion. Mind-made hypotheses are not investigations of nature. No hypothesis is justified in natural inquiry unless it rests upon facts. The man who scorns facts is no natural inquirer." Such were my words in the Preface to my Swallowtails.

This handwriting tells us in the most convincing and palpable manner, how one species passes into another, and how the species are segregated. Nowhere has the actual origin of species and the connexion of a concatenated series of species been hitherto so forcibly exhibited and demonstrated as here.

Let us look at the facts more closely.

In the first part of my Artbildung und Verwandtschaft bei den Schmetterlingen, in the Section on Die segelfalterähnlichen Papilioniden, I have derived the last-named butterflies from forms which had eleven longitudinal stripes on their wings, such as are still shown to-day by certain species like P. Alebion, Paphus, Glycerion. Now these longitudinally striped ${ }^{1}$ butterflies give, as I am becom-

1 The objection has been raised on many sides that what I call longitudinal striping in butterflies is really a transversal striping of the wings. And this is quite correct if we speak of the marking of only a single wing. But I speak of the marking of the entire butterfly, of its body, and its two wings, of the front and the hind 
ing more and more convinced, the fundamental form of marking of all diurnal butterflies. Partial or total disappearance, broadening and fusion of the fundamental bands condition the formation of the characteristic marks of aberrations, varieties, species, and families. From the transformations of the fundamental bands and the intervening spaces, the ocellated spots also are produced.

In the majority of Segelfalter some of the eleven bands have already disappeared or have been shortened from behind forwards.

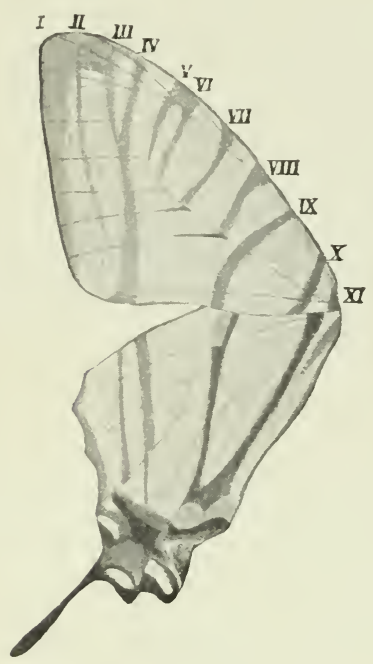

Cut r. Papilio Alebion Gray.

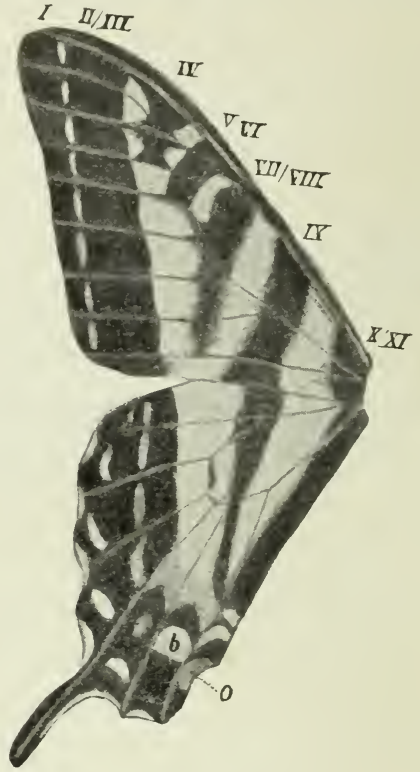

Cut 2. I. Eurymedon BorsD.

The case is similar with those Swallowtails which are their nearest relatives.

I reproduce here a representation of Alebion from above ${ }^{1}$ with

wings as integral parts of a whole. That the wings are a whole with respect to marking is proved by the connexion of the marking in front and behind, in the position which the wings assume when spread out and where the marking and the coloration, owing to the hind wings being covered by the fore wings, are partly wanting. The connexion in question is likewise proved by the mode of transformation or disappearance of the markings from behind forwards, from the hind wings to the fore wings; in other words, by the existence of general laws of marking in such transformation. For details see my Artbildung, II., 48, 49.

${ }^{1}$ In the following cuts the left wings always give the upper sides, the right wings the under sides. 
its eleven fundamental bands marked by capital Roman numerals, designations which I have everywhere employed in my Artbildung und Verziandtschaft bei den Schmetterlingen, and which I shall also lay at the basis of the description to follow. For all the markings of the diurnal butterflies can be traced back to these bands and to the black coloration of the veins.

Also the following cuts of the Swallowtails have been taken from my Artbildung. In the footnotes added to the descriptions will be found numbers and plates referring to the corresponding colored cuts of the last-mentioned work.

The form of living Swallowtails which in most likelihood is nearest allied to the initial form of the group, and which is most nearly connected with the Segelfalter, namely Papilio Eurymedon (Cut 2), has as yet only seven longitudinal stripes; the remaining ones have partly disappeared and have partly been fused at the sides. As in the Segelfalter, they disappear in the succeeding species, by orthogenesis, from behind forwards, conformably to the law of postero-anterior development, Papilio Turnus, P. Alexanor, P. Machaon.

In $P$. Alexanor there are, as Cut 3 on p. 40 shows, still seven stripes present either in part or in whole, I, II, III, V/VI, VII/VIII, IX, XI. V/VI is, here as always, situated on the fore wings at the outer border of the middle cell. IX forms with XI an angle, and is on the under side frequently colored black, white, and red, or black, white, and yellow ("ornamental band"). C on the outer border of the middle cell of the hind wings like Vy VI is here as in other families, e. g., in the Pierids, an extremely important marking, in its origin probably a component part of VII/VIII, which in some Segelfalter reappears rudimentarily but in the Swallowtails is a pronounced " $\mathrm{C}$-marking."

The remaining transformations of the bands of Swallowtails are the consistent expression of the general law of markings, first in that they exhibit spots which are due to abridgement and lateral fusion as in P. Machaon in Europe and North America, ${ }^{1}$ and further

${ }^{1}$ Plate VI. Fig. 8. 
in that they show rudiments of transversal stripings induced by the blackening of the cross veins (noticeable in other specimens of Machaon). These rudimentary transversal stripings are by other agencies subsequently perfected, as in the case of $P$. Xuthus and Xuthulus. ${ }^{1}$ Here, on both sides of the wings, and that, too, in the forward middle cell, a transversal striping makes its appearance (a, Cut 5).

In P. Hospiton (Cut 7) there is a rudiment of this new marking present.

Finally unicoloration arises, as follows. The dark coloring

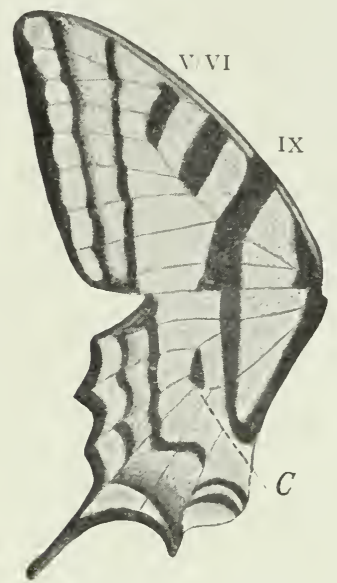

Cut 3. Papilio Alexanor Esp. \&.

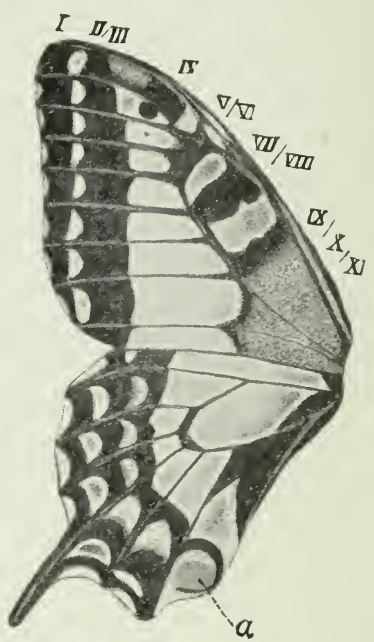

Cut 4. Papilio Machaon bimaculatus m.

which has made its incipient appearance at the inner wing-angle of Machaon extends systematically outwards over the wings and ultimately covers their entire surface, excepting a few spots at the border (Asterias group, Cut 6). ${ }^{2}$

We have accordingly a simplification of marking and coloring in the higher forms and not a perfection, as Nägeli's theory and as sexual selection would require. The same holds true of the tails of the hind wings which in the higher forms are not lengthened but shortened. And both facts hold true of the Segelfalter. 
The directions of development of these markings show accordingly in their systematic conformity to law the same detailed tendencies as are determinative in animals quite unallied to the butterflies, as in mammals, birds, lizards, mollusks, etc.

The gradual transformation of the markings takes place therefore, as the cuts and particularly the plates of my book show, for the most part through the disappearance, shortening, and lateral fusion of the bands, in which process the upper side as a rule is considerably in advance of the under side which largely retains

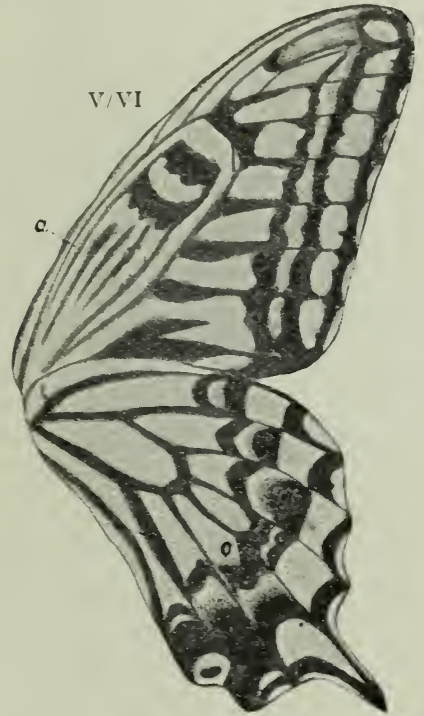

Cut 5. Papilio . Tuthus L. (Under surface.)

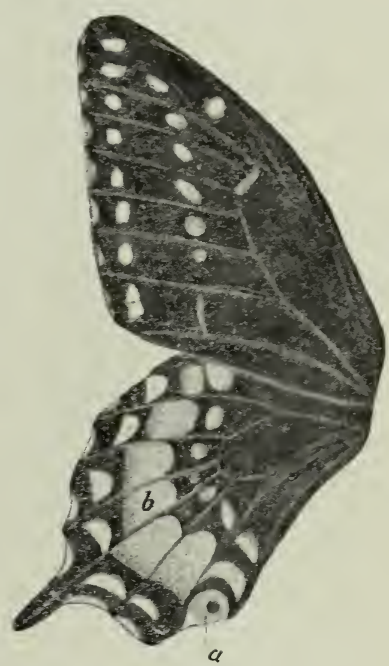

Cut 6. Papilio Asterias Cram. .

the earlier and more primitive condition, - a result the very reverse of that demanded by the theory of adaptation for diurnal butterflies.

In addition, new bright colors and color-markings and embellishments make their appearance, at first mostly as before on the upper surface, as the bright blue inner marginal band which conformably to postero-anterior development first appears at the back and developing itself on the hind wings afterwards advances forwards (P. Turnus, Plate V, Machaon, ${ }^{1}$ Asterias-group $\left.{ }^{2}\right)$. And if 
this band is more pronounced and more beautiful on the under side than on the upper, on the other hand it did not make its appearance there until subsequently when it was either on the verge of disappearing above or had already disappeared (P. Troilus, ${ }^{1}$ Palamedes $\left.^{2}\right)$.

At the inner angle of the hind wings, the ornamental hinder eye, as in the Segelfalter, is developed from portions of the mar-

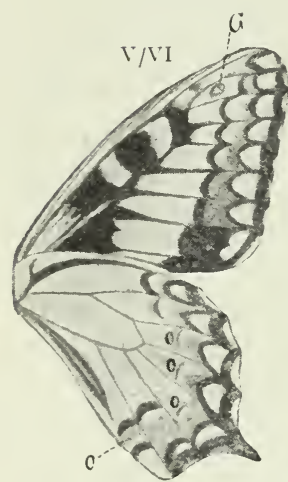

Cut 7. Papilio Hospiton GÉNÉ. Under surface.

The three 0 's on the hind wing indicate the points where orange-red (reddish-yellow) spots lie.

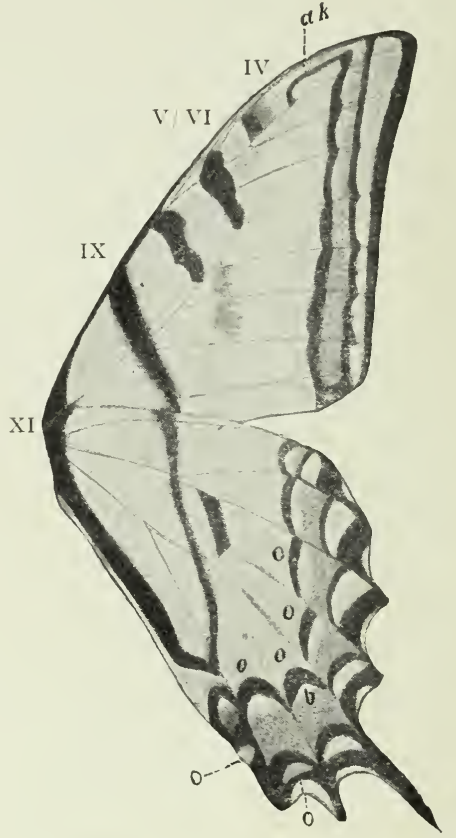

Cut 8. Papilio Daunus BonsD of. Under surface.

The four 0 's on the interior of the hind wings show the places where orange-red spots are situated.

ginal bands, as comparison with the more primitive under side frequently shows, e. g., Papilio Hospiton (compare Cut 7 at the point $o$ outside the Cut). ${ }^{3}$

Quite remarkable is the slow, systematic production from a fragmentary black band, of a black nucleus in the orange-red hinder eye, particularly in Machaon and Asterias. Whilst the upper side

${ }^{1}$ Plate VIII. Fig. $2 \quad{ }^{2}$ Idem, Figs. 3 and 4 , etc. $\quad{ }^{3}$ Plate VI. Fig. 6. 
is usually in advance of the under side in development, the reverse also takes place, as, for example, in the production of orange-red spots, which again originate first on the posterior part of the hind wings within the innermost black marginal band in the cells of the wing on the under side, ${ }^{1}$ as in $P$. Machaon and in $P$. Hospiton $(o$, Cut 7), ${ }^{2}$ and further in P. Turnus, Daunus (the four inner $o^{\prime} s$ on the hind wings of Cut $8^{3}$ ), and which gradually increase in intensity of color and in magnitude, to spread finally over the wing cells of the

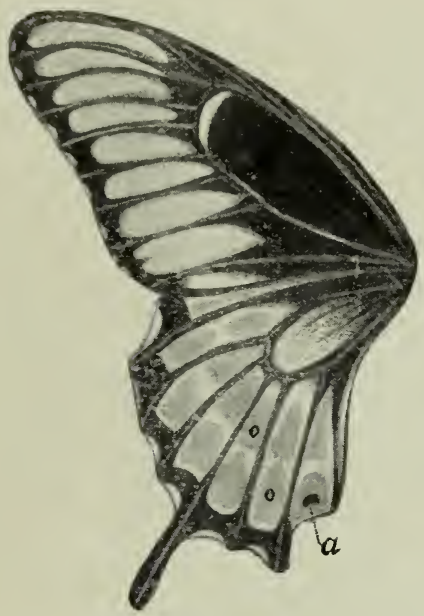

Cut 9. Papilio Asterias var. Calverleyi Grote.

The $o$ 's indicate two series of reddishyellow spots. The $a$ shows the nucleus of the hinder eye-spot.

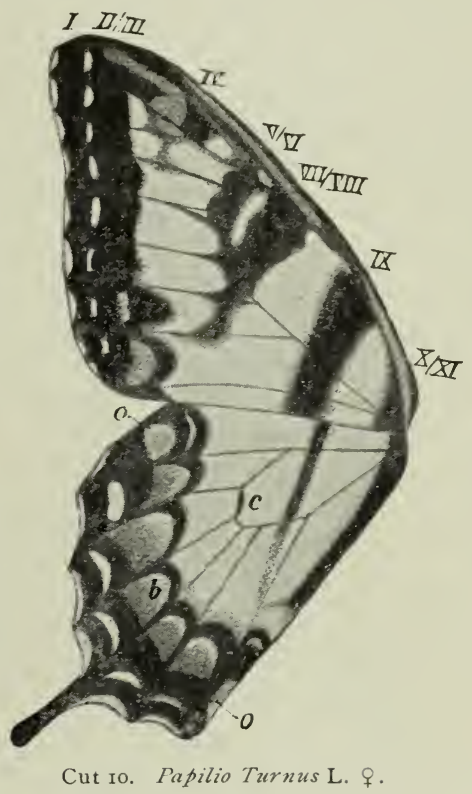

Cut ro. Papilio Turnus L. + .

fore wings ( $P$. Brevicauda, $P$. americus, $P$. Hellanichus ${ }^{4}$ ). In the last-named butterfly they are also present on the upper side, as they are in Calverleyi ( $O$ on the hind wing, and corresponding neighboring spots, Cut 9). ${ }^{5}$

It is noteworthy of $P$. Turmus that these spots appear first more prominently in the female. ${ }^{6}$ In $P$. Bairdii the reverse is the case. ${ }^{7}$

\footnotetext{
${ }^{1}$ Plate V., VI.

${ }^{2}$ Plate VI.

${ }^{3}$ Plate V.

${ }^{+}$Plate VII.

${ }^{5}$ Plate VIII. $\quad{ }^{6}$ Plate V. Fig. 2. $\quad{ }^{7}$ Plate VII.
} 
Similarly in the sulphur-yellow spots of the outer marginal band orange-red dots make their first appearance underneath (Turmus). In the higher forms these spots are found only in the cells of the fore wings and have disappeared (Cut 9) in the two hind wings (P. Asterioides and Asterias). ${ }^{1}$ The foremost of these spots is in Turnus carried over to the upper surface (compare Cut ro, the $o$ to the front), as also in Troilus $;^{2}$ and in the same place, as also rudimentarily in the remaining cells of the hind wings as well as in the hindmost cell of the fore wings, a like coloring appears also in $P$. Machaon asiatica, ${ }^{\circ}$ and it is this coloring that everywhere produces the orange-red of the hind eye-spot in the innermost cell of the hind wings (e. g., o in Turnus Glaucus of, Cut I9, $a$ in Papilio Bairdii $0^{\lambda}$, Cut I5).

An extremely remarkable direction of development in the transformation of the markings is manifested in the fact that on the under surface of Machaon rudiments of that streaking of the middle cell of the fore wings first appear which in Xuthus and Xuthulus become more pronounced in development, are present on both sides, and constitute a prominent characteristic of this species (compare P. Hospiton, Cut 7, P. Xuthus, Cut 5, and Hippocrates, ${ }^{4}$ also P. Machaon astivus).

Numerous other systematic and law-conforming transformations of marking and coloring might readily be cited.

Instead of doing so, however, we shall proceed to examine a few newly appearing characters in our Swallowtails.

The new characters in question make, as I have already shown for the Segelfalter, their first appearance in a very inconspicuous and scarcely perceptible manner. Like all other modifications they are first produced in single butterflies of a species only as aberrations, then they appear as characteristics of varieties, and finally as marks of species.

In this manner certain tiny black dots make their appearance in the cells of the fore wings of Swallowtails, at first partly as marks

\footnotetext{
${ }^{1}$ Plate VII. $\quad{ }^{2}$ Plate VIII. Fig. 2. $\quad{ }^{3}$ Plate VI. Fig. $7 . \quad{ }^{4}$ Plate VI.
} 
distinguishing aberrations and partly even as such distinguishing species.

For example, in the forked cell of Machaon there is found, usually at both sides, but always on the upper surface, a black point or spot, which is also present and has become a mark distinguishing the species in Xuthus and Xuthulus and in several members of the Asterias group (compare P. Hospiton, Cut 7, at G; P. Machaon bimaculatus, Cut 4 ; P. Xuthus, Cut I I P. Bairdii ${ }^{7}$, Cut I 5). In $P$. Turnus $q$ and in $P$. Alexanor, etc., there is found in place of

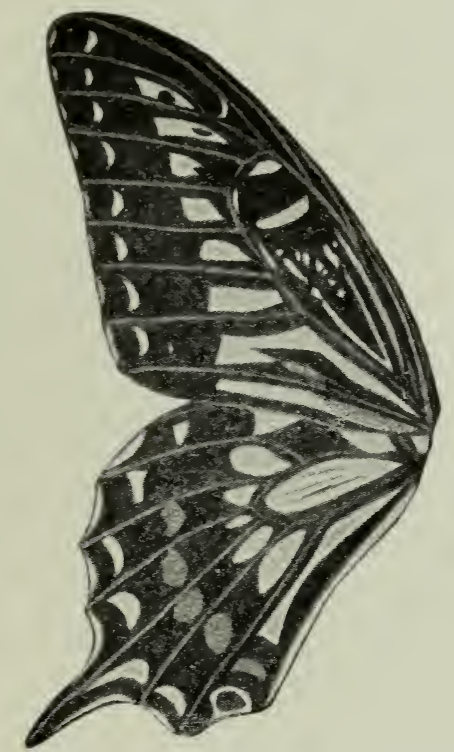

Cut II. Papilio Xuthus L. (Upper surface.)

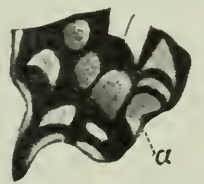

Cut 12. Papilio Machaon asiatica Mén.

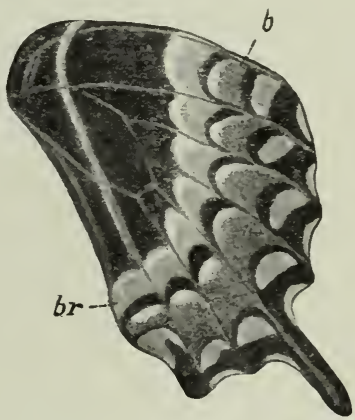

Cut 13. Papilio Palamedes DRU. C.

Hind wing, under surface. $b r$, brownish-red. $b$, blue (blue marginal band).

this an outwardly protruding fragment of band IV., ${ }^{1}$ from which it has doubtless originated. In many Machaon (e. g., Hospiton) the black spot acquires as a new character a bright space in its centre (compare the cut).

So also in the bright interior of the first lateral margin-cell which lies just behind the forked cell, is sometimes found a very

${ }^{1}$ In the address as printed in the Compte-Rendu, page $6_{3}$, band IV. reads erroneously band $\mathrm{V} / \mathrm{VI}$. 
small but very distinct dot in some of our native $P$. Machaon (compare $P$. M. bimaculatus, Cut 4). It is likewise found in a butterfly of Allahabad. ${ }^{1}$ In $P$. Xuthus (compare Cut II) it is always present on the upper surface and only seldom as a small transversal streak; it is usually found as a large oviform spot, and from the marking which appeared in Machaon as an aberrational phenomenon it has in this last stage been converted into a conspicuous and distinguishing mark of the species.

A new phenomenon is the appearance of a dark outward border on the middle cell of the hind wings, which on the under surface of Turnus occupies the entire outer margin, but on the upper surface makes its appearance only as a black line of varying shortness -the $C$-marking as I have termed it and which is very conspicuous for example in P. Turnus $\sigma^{\top}$ (Cut Io C), Daunus (Cut 8), Pilumnus, but particularly in Alexanor (Cut $3 C$ ). In Daunus 9 it is present only on the under surface; in the majority of $P$. Machaon the entire border of the middle cell is black also on the upper surface, as it is also in the majority of Asterias. $^{2}$

Another new character is the black nucleus in the hinder eyespot which is already pronounced in appearance in many members of the Machaon group, e. g., P. Zolicaon and P. Machaon var. oregonia, and then in Asterias, and whose origin from a fragment of marginal band has already been mentioned. We recognise the first stage of its production in Cut ig representing $P$. Turnus Glaucus 9 , just above the letter $g$; in $P$. Machaon asiatica (Cut I2) at the letter $a$, and in $P$. Palamedes $\sigma$ (Cut 13 representing the under surface). A more advanced stage is seen in P. Bairdii $\sigma^{\top}$ (Cut I5), to the right above $a$. The nucleus of the hinder eye-spot is completed, that is, perfectly marked off, in P. Bairdii o (Cut I8), T. asterioides $\sigma^{\pi}$ (Cut $\mathrm{I} 6$, both times at $a$ ), P. Xuthus (Cut II), etc.

${ }^{1}$ Compare for the case of Machaon Cut A at page 25 of my Sivallowtails.

${ }^{2}$ Colored and even red borders of the outward angle of the middle cell of the hind wings were observed even among the Segelfalter in the case of P. Protesilaus (Segelfalter, Plate I. Fig. 5), but without assuming any further import. As for the rest it was pointed out that the $C$-marking was probably a reappearance (reversion) of a fragment of band VIII. 
A new and very marked character, distinguishing the majority of Swallowtails in the broadest sense, finally, is the blue marginal band, the blue spots of which are marked $b$ in a number of the following cuts (P. Bairdii, Turnus Glaucus, of Palamedes, Daunus, Asterias).

Part of these new characters, which in the end appear as fresh marks distinguishing the species, is accordingly to be regarded as a transformation of old characters, whilst another part is entirely new.

Now these new characters, viz., the tiny dots and lines here making their first appearance, can be observed in their first, primitive origin, and can be followed in their development from almost imperceptible markings as they appear here and there in individuals of a species, until they have become fixed as permanent marks of a different species. The ids and determinants of Weismann cannot be seen. But one can palpably and irrefutably see in the faint dots here considered that the transmutation and origin of a species has taken place in diametrical opposition to the theory of determinants. The same is proved by all transformations of existing characters into new distinguishing marks of species. The origin and perfection of new characters, the transmutation and origin of species, take place conformably to law in a few, quite definite directions without any "oscillation" 1 whatever, without any reference to utility; they demonstrate, in fact, the absolute impotency of natural selection in this domain.

One can read from my plates how all the characters of the different varieties and species of swallowtailed butterflies have arisen one from another by orthogenesis. Every variety or species is distinguished by a definite total of characters which have originated orthogenetically from the most inconspicuous beginnings, which through heterepistasis on the one hand, homöogenesis on the other, and finally through halmatogenesis, have been developed and compounded now in this manner, now in that; whilst the upshot of the whole shows that the origin of species essentially re-

${ }^{1}$ See Germinal Selection, p. 20, where Weismann contends that the variations presented to selection "oscillate" about a given zero-point._Trans. 
poses on genepistasis or cessation of development at different single stages of the evolutionary advance, the process being that one species thus always presents a higher stage of development in its characters than another.

That utility plays no part whatever in the process follows from the nature of the determinative characters themselves, but is particularly demonstrated by the following considerations: (I) In different species of the same phylogenetic line, the various stages of these characters never occur in the same perfection or arrangement; (2) they are equally determinative in different parallel chains of species; (3) they also occur side by side in different sexes in different development; (4) they occur in the same development in different species of one phylogenetic line-apart from the fact that (5) they everywhere make their appearance in the most inconspicuous beginnings, are preserved in faint forms of perfection as distinctive marks of species and may disappear again, and that (6) the complete reversion of all characters so originating, or their concealment through being colored black, that is perfect simplification, may arise.

The significance of heterepistasis for the origin of species is everywhere forced on our notice by my cuts, and I shall draw attention here only to a few special conspicuous features.

In Machaon the uniform black coloration of the upper surface of the roots of the forewings has become characteristic of the group. In Xuthus and Xuthulus this character has not reached its full perfection, although the reverse is the case with the striping of the middle cell of the fore wings, which is rudimentarily indicated only in a few Machaon, not having attained there further development. Hellanichus receives a very special character from the running over of the orange red color-spot on the under surface of the wings to the upper surface. The Turmus have lost much of their original marking, in that the original longitudinal stripes have been not only shortened from behind forwards, but also diminished in width. Particularly the male of this butterfly, ${ }^{1}$ which has advanced quite 
far in transformation, has been made very bright in this manner. Also in Machaon the longitudinal stripes have disappeared from the back to the front, but in this instance the black coloring of the transverse veins has set in.

The widening of the residual stripes of the fore wings and the black coloration on the upper surface of the roots of the same by the fusion of the longitudinal stripes points to a direction of development which is the opposite to that in Turnus.

This last direction of development, the appearance of a uni-

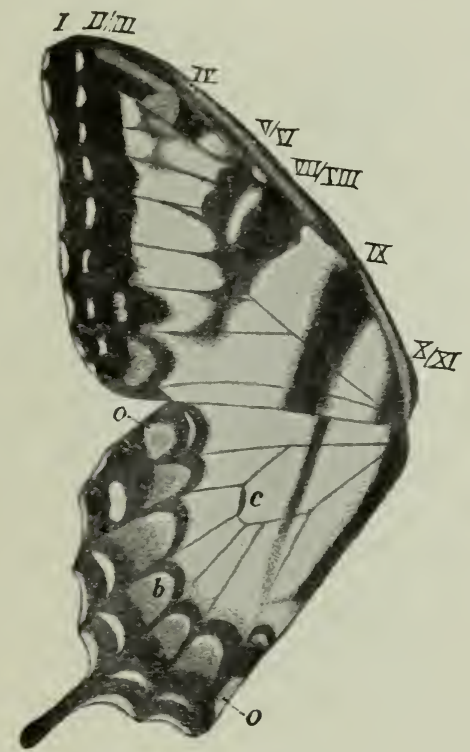

Cut If. Papilio Turnus L. $q$.

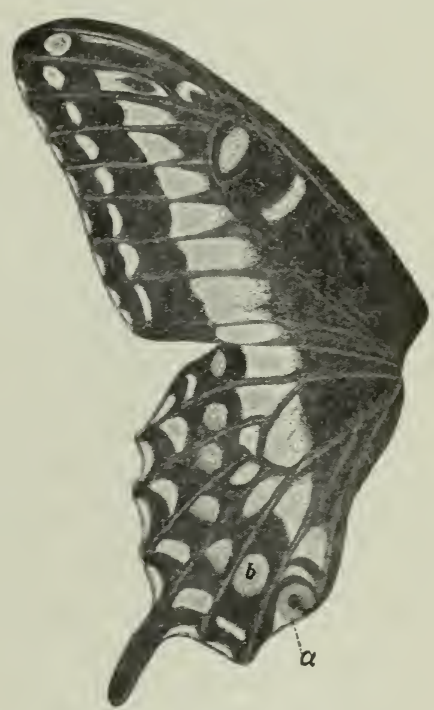

Cut 15. Papilio Bairdii Edw. \&.

form black coloration on the roots of the fore wings, which even in Machaon had begun to extend to the hind wings, continues to spread in Asterias to both wings, and in the Asterias group makes for unicoloration or perfect black coloration. This progressive blackening offers, coincidently with two instances of saltatory development (halmatogenesis), conspicuous examples of independent similarity of development, homöogenesis, and of female preponderance, whereas otherwise male preponderance is usually determinative. The same phenomena suddenly assumes in Bairdii ㅇ and in Turnus var. Glaucus 우 so advanced a stage as to ex- 
tend over the entire wings with the exception of a few spots, whereas the average female of Turnus is sulphur-yellow in its ground color like the male, and whereas in the males of Bairdii the black coloring is only somewhat more extended than in Machaon. In other words, the phenomenon which in Bairdii o and Turnus Glaucus spasmodically and suddenly developed, and only in the female, was, beginning with Machaon, gradually perfected in the Asterias group in both sexes. The black coloring kept extending here from species to species, beginning at the roots of the wings and spreading over their entire surface, at last leaving be-

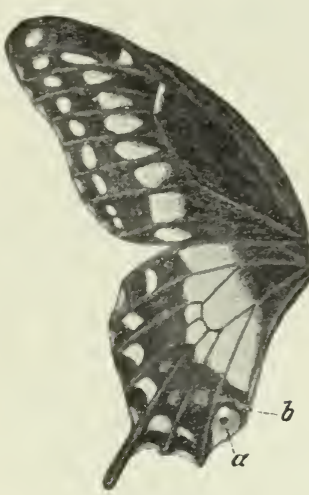

Cut i6. Papilio asterioides REAK. + .

$b$ and the three spots situated in the wing cells just above are blue (blue marginal bands).

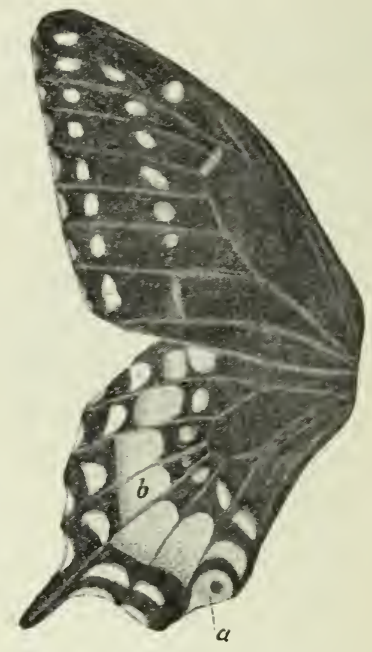

Cut 17. Papilio Asterias URAM. + .

hind it only bands of spots of the ground color, - the same as were left in Bairdii , whilst in Turnus Glaucus even these were lost.

The butterflies represented in Cuts 14 to I9 show accordingly a series of different stages of law-conforming transmutation of species, which exhibit not an advance towards beauty and variety, but an advance towards simplicity, towards dark and sombre colorings, such as I have described among the Segelfalter, and such as appear widely distributed as we shall see later on among other groups of butterflies. Sexual selection, as being on the face of it absolutely excluded so far as the markings and coloration of butterflies are concerned, is nowise involved here, nor is there any 
ground for believing that selection or adaptation is in any way concerned.

The species $P$. americus, Nitra, Indra, brevicauda, asterioides, and Asterias figured on Plate V'II. of my Schwalhenschwanzähnliche Schmetterlinge, ${ }^{1}$ show a complete serial line of transformations within the Asterias group, and are at the same time conspicuous examples of genepistasis. The highest degree of transformation in this series has been reached by Asterias, a species which is almost as far advanced as Bairdii + . P. Troilus ${ }^{2}$ is almost as far ad-

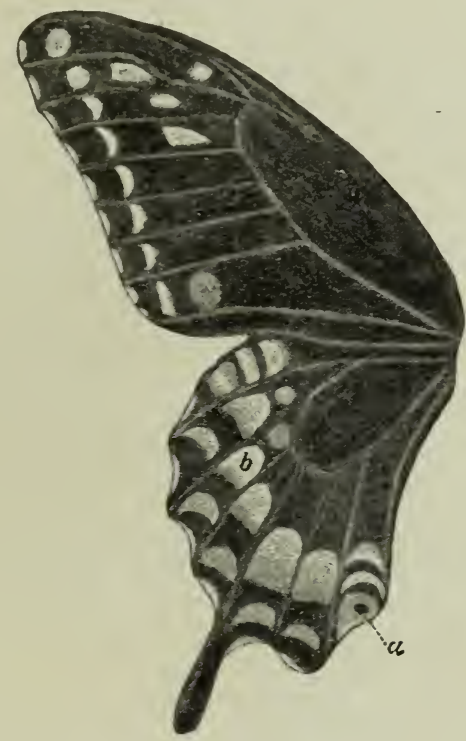

Cut 18. Papizio Bairdii Edw. 9 .

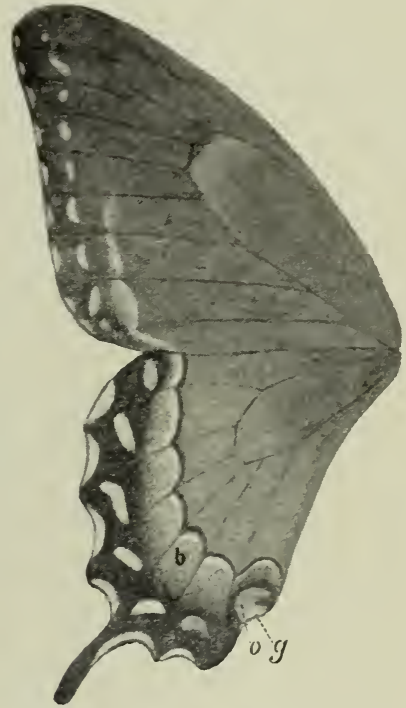

Cut 19. Papilio Turnus Glaucus L. $\subsetneq$.

vanced on the other side and represents an instance of heterepistasis as does also Palamedes.

We have figured still another butterfly which is most likely a conspicuous instance of halmatogenesis: Papilio Asterias rar. Calverleyi, Cut $9,{ }^{3}$ which according to Edwards is probably a cold form of Asterias. It has been transformed towards the Machaon type in

${ }^{1}$ The cuts given in the present pamphlet are in fact a makeshift only, for the purpose of explaining the description. I must refer to the plates of my Artbildung, etc., for a full understanding of the facts.

\footnotetext{
${ }^{2}$ Plate VIII. Fig. $2 . \quad{ }^{3}$ Plate VIII. Figs. 5 and 6.
} 
such wise that the black occupies only the inner part of the wings, whilst the broad outward parts of the same have turned yellow or orange-red, the latter color appearing on the hind wings, where the orange-red coloring of the wing-cells which in various other species of the Asterias group has been specially developed on the undersurface, attains great importance also on the upper surface.

The black P. Turnus Glaucus 9 is as compared with the common bright female type of Turnus a more southern form living in warmer regions, so that here also climatic conditions seem to be decisive of transformation. This does not hold, however, for the dark Asterias, for these occur also in colder regions. Since female preponderance is determinative of the transformation in Turmus Glaucus and in Bairdii, and since this transformation corresponds entirely to that of Asterias, therefore the influences upon the weaker female sex which in this case is more sensitive must be sought as the cause of the transformation, and the more so because Glaucus $q$ appears also in the North in isolated cases among the common Turnus.

The facts here presented also afford a conspicuous example of the ease with which mimicry may erroneously be assumed and notoriously has been assumed by writers who need it in its full extent for the substantiation of their hypotheses. In the many various species of the Asterias group we should have the most beautiful instances of mimicry imaginable, were it not that these species have developed and are now living entirely without biological connexion. What perfect specimens of mimicry P. Turnus Glaucus o , Asterias, Bairdii, etc., would present to the enthusiastic devotee if he could only furnish the facts of biological connexion : Finally, in strict agreement with the instances which the devotees of mimicry have put forward, not only all the members of the Asterias group but also all of the Machaon and all of the Turnus groups must be regarded as mimetic. And I should scarcely be surprised if Pseudo-Darwinism were really to advance this contention.

It will immediately be evident to the unprejudiced observer, however, that the resemblances are the result of developmental 
tendencies, and that independent sameness of development or homöogenesis is determinative of likeness, even in not immediately related forms.

As a fact, there is no doubt in my mind, that when the data have been carefully sifted, it will certainly be shown that by far the greater majority of cases of so-called mimicry have nothing to do with adaptation. It was to this purport that the entomologist Hahnel spoke long ago, from actual numerous observations which he had made in South America in nature; whereas Erich Haase ${ }^{1}$ without having looked to actual nature at all, has recently set up no end of cases of mimicry on the basis of outward similarity between butterflies, and wrote a whole book on the subject. But it stands to reason that resemblances of this character, quite apart from the question of their origin, can prove nothing for adaptation. The demonstration of adaptation in nature itself is alone decisive.

As to the origin of actual cases of mimicry the same cannot possibly be explained by selection, and what Herr Weismann has recently said ${ }^{2}$ about Kallima as a marvellous product of selection loses all its demonstrative force when opposed to the plenitude of facts which go to show that orthogenesis everywhere determines the shaping of characters and is in this manner enabled to produce the resemblance to a leaf on the under-surface of a butterfly, and that homöogenesis is able to bring about the greatest resemblance between two butterflies which do not live together at all-a phenomenon of which numerous cases are known. ${ }^{3}$ There is similarly nothing marvellous about the systematic and proportionate extension of the leaf-marking of Kallima from the fore wing to the

${ }^{1}$ Erich Haase: Untersuchungen ïber die Mimicry auf Grundlage eines natürlichen Systems der Papilioniden. Kassel, I894.

${ }^{2}$ International Congress of Zoologists at Leyden, Sept. 16, 1895. The Monist, Jan., I896. Germinal Selection, Chicago, I896.

${ }^{3}$ Piepers in the entomological section of the Leyden Congress of 1895 referred to cases of this kind. Thus, Junonia Asterie of Java is like our Hipparchia Megara, and Junonia Erigone, of the same locality, resembles our Hipparchia Egeria, so that in both cases mimicry would would have been assumed if the like butterflies had lived together. Further facts will be given later. 
hind wing while skipping the posterior margin of the fore wing so far as this is covered by the hind wing. The same phenomenon is everywhere noticed and is obviously a consequence of the action of light or of lack of light. Selection can create nothing new. It can only work with what is already present. Once the similarity of the wings of a butterfly to a leaf has been produced, it can be useful and further development can then doubtless be favored by selection. The origin of the resemblance, however, cannot be due to accidental variation, which is supposed to have all possible characters ready for selection. Kallima's resemblance to a leaf is determined by a thousand and one details. Not one accident but a thousand accidents together would have been requisite, and would have had to present themselves suddenly, in order to produce this resemblance by the selectional agency of Darwinism. The resemblance to a leaf could not have gradually arisen by selectional means; it must have originated suddenly and in approximate perfection in order to have given selection any hold for its operations.

There is no chance in the transmutation of forms. There is unconditioned conformity to law only. Definite evolution, orthogenesis, controls this transmutation. It can lead step by step from the simplest and most inconspicuous beginnings to ever more perfect creations, gradually or by leaps; and the cause of this definite evolution is organic growth.

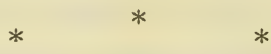

It was not chance that I announced "Orthogenesis and the Impotence of Natural Selection in the Formation of Species" as the subject of my address before the Leyden Congress, and that my opponent without my previous knowledge spoke several days before me on the same subject, viz., definitely directed evolution; in other words, that both of us, independently of each other, had determined to speak on the same subject. I had long expected that the creator of the hypothesis of germ-plasm would sooner or later attempt to annul in his characteristic fashion the significance of definitely directed evolution, this deadly enemy of his doctrines, and from my previous experience I was not at all surprised at its 
being done to the utter neglect of the facts which I had established, and of all facts that contradict his position.

Theorising has its place and justification in natural research varying in amount in the opinion of different individuals, according to the varying type of mind, education, and knowledge.

But one thing is beyond all question. The tiniest fact, if it have some determinative bearing upon great problems, is of more value than a whole edifice of lofty theories which cannot stand before that fact. And again, any theorising which sets up a claim to recognition in natural research must not stand in contradiction to facts, it must not suppress facts.

The person who will not make allowance for facts in shaping his hypothesis, has renounced all claim to the title of natural inquirer.

And such a procedure must inevitably revenge itself upon the hypothesis which it is intended to protect. For the facts will sooner or later show that the hypothesis is not capable of life and never was.

And so the hypothesis of germinal selection propounded to explain definitely directed evolution was refuted by the facts before it was excogitated-it was a still-born child.

After having begotten so many children which he afterwards cast off, the father of this new hypothesis will not take it amiss in me when I prognosticate the fate of this, his latest child.

The facts of orthogenesis established by me, which are visible to a!l who will see the truth, alone refute the entire body of hypotheses regarding the germ-plasm.

Other no less palpable facts also annul the views which my opponent asserted in his address with regard to the causes which transform the parts of skeletons, and they enforce in the clearest manner the proof of the heredity of characters acquired by use. The entire comparative anatomy of the skeleton is a proof of this heredity, and the doctrine of germ-plasm is most signally put down by the law of compensation, which, although touched upon by Geoffroy-St. Hilaire, Goethe, and others, has hitherto met with little notice, but which, taken in connexion with the transformative 
activity of the parts, controls the entire skeletal structure of vertebrate animals. ${ }^{1}$ And so it is again palpably incorrect to assert, as my opponent has done, that the single characters of a body through accidental variation are subjected to selection, each on its own accord. The organism is a whole, the parts of which are not only physiologically connected but are dependent on one another also in their genetic morphology.

It is the function, the activity, the use of the parts that together with definite evolution, orthogenesis, determines the morphological growth of living beings.

${ }^{1}$ This I shall show from observations shortly to be published by me. 
$\because$ 




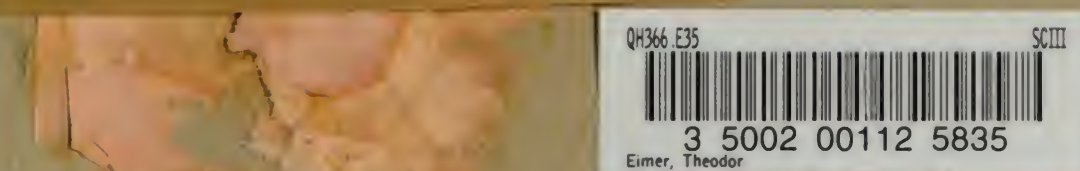

orthogenesis : and the impotence of $n$

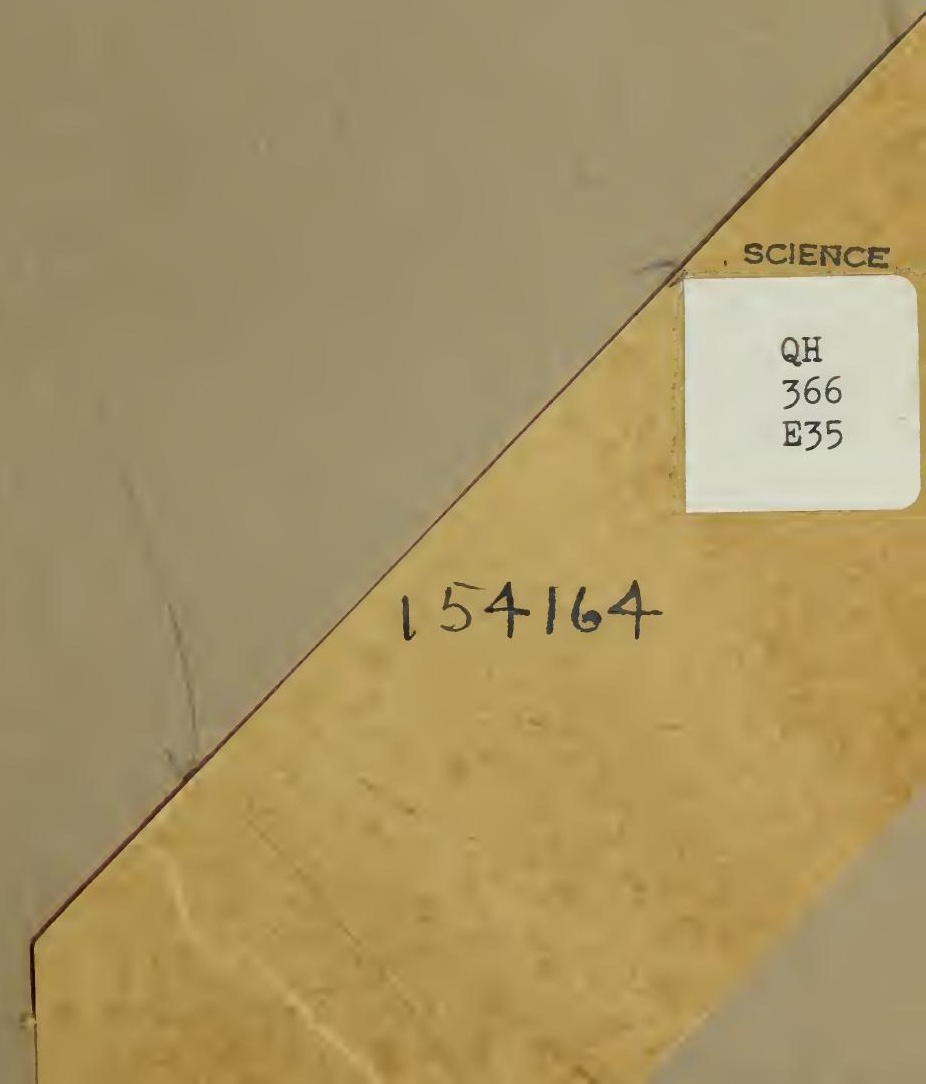


